\title{
Inactive Sulfide Ecosystems in the Deep Sea: A Review
}

\author{
Cindy Lee Van Dover* \\ Division of Marine Science and Conservation, Nicholas School of the Environment, Duke University, Beaufort, NC, \\ United States
}

\section{OPEN ACCESS}

Edited by:

Daniela Zeppilli, Institut Français de Recherche pour l'Exploitation de la Mer (IFREMER),

France

Reviewed by:

Malcolm Ross Clark,

National Institute of Water and Atmospheric Research (NIWA),

New Zealand

Eva Ramirez-Llodra

Norwegian Institute for Water

Research (NIVA), Norway

Antje Boetius,

Max Planck Institute for Marine Microbiology, Germany

*Correspondence:

Cindy Lee Van Dover clv3@duke.edu

Specialty section:

This article was submitted to Deep-Sea Environments and Ecology, a section of the journal

Frontiers in Marine Science

Received: 15 March 2019 Accepted: 10 July 2019

Published: 23 July 2019

Citation:

Van Dover CL (2019) Inactive

Sulfide Ecosystems in the Deep Sea: A Review. Front. Mar. Sci. 6:461. doi: 10.3389/fmars.2019.00461
Polymetallic seafloor massive sulfides that are no longer hydrothermally active are a target for an emergent deep-sea mining industry, but the paucity of ecological studies and environmental baselines for inactive sulfide ecosystems makes environmental management of mining challenging. The current state of knowledge regarding the ecology (microbiology and macrobiology) of inactive sulfides is reviewed here and attention is given to environmental management considerations where lack of knowledge impedes informed policy recommendations and decisions.

Keywords: polymetallic sulfides, seafloor massive sulfides, hydrothermal vent, deep-sea mining, environmental management, microbiology, ecology, chemosynthesis

\section{INTRODUCTION}

There is growing interest in mineral resources of the deep sea, including polymetallic nodules, crusts, and sulfides (Miller et al., 2018). Of these resources, polymetallic sulfides are distinct in that metal-rich sulfide minerals are deposited on and in the ocean crust as a consequence of hydrothermal reactions between seawater and hot rock (Petersen et al., 2016a). In the modern deep ocean, sulfide minerals are best known from hydrothermal processes where chemically modified and thermally buoyant $350^{\circ} \mathrm{C}$ fluids exit the seafloor as black smokers. There, metal sulfides rich in iron (pyrite), copper (chalcopyrite), and zinc (sphalerite), among other elements, disperse into the water column as hydrothermal plumes or precipitate at the orifice and in subsurface conduits during the constructive phase of black-smoker chimneys and mounds. At the seabed, hydrothermally active sulfides support dense communities of specially adapted invertebrate taxa that rely on bacterial chemoautotrophic primary productivity (Van Dover, 2000). Black smokers and sulfide deposition are active on timescales that vary from days (or shorter), to decades (Macdonald et al., 1980), and-albeit intermittently-for 100's of thousands of years (Lalou et al., 1995, 1998; Cherkashov et al., 2010; Liang et al., 2018) at a given location. A key environmental feature is that the surface area of the largest known active sulfide occurrences is small, $<0.03 \mathrm{~km}^{2}$ (German et al., 2016), i.e., 14 times smaller than the area occupied by Vatican City (see Dimensions and Distributions of Inactive Sulfide Occurrences and Potential Sulfide Ore Deposits for more on the dimensions and distributions of inactive sulfides).

Ultimately, hydrothermal activity (i.e., flow of chemically modified fluids) wanes and then ceases; the sulfides become 'inactive.' This inactivity may be effectuated relatively rapidly (from hours, days, weeks, and years, to centuries) through local processes (including clogging of chimney conduits through mineralization, tectonic activity that alters chimney or subsurface plumbing, volcanic activity that paves over existing chimneys with lava) and more regional processes that take place over geological timescales (millenia to mega-anna; including quenching of the underlying heat source, migration off-axis through seafloor spreading). Where hydrothermal activity continues for long durations (several thousands of years or more), minerals of potential commercial value, 
including chalcopyrite and sphalerite, can accumulate to form deposits of sufficient size and quality to be of interest to an emergent deep-sea mining industry (Strens and Cann, 1986; Hannington et al., 2011; Petersen et al., 2016a, 2018; Andersen et al., 2017). Based on available heat, the mass and metal chemistry of circulating $350^{\circ} \mathrm{C}$ fluids, and reasonable metal deposition efficiencies, metal resources of massive sulfides formed by global seafloor hydrothermal systems are calculated to be many hundreds of times that of total known massive sulfide reserves on land (Cathles, 2011).

From an ecosystem perspective, the transition of a hydrothermal sulfide from hydrothermally active to hydrothermally inactive is marked by a profound change in the dominant source of electron donors that sustains local chemosynthetic productivity, namely from dissolved sulfide and other reduced compounds in hydrothermal fluids to reduced iron and sulfur of solid minerals (Sylvan et al., 2012). In addition, as hydrothermal activity wanes and then ceases, obligate thermophilic $\left(>45^{\circ} \mathrm{C}\right)$ and mesophilic $\left(20-45^{\circ} \mathrm{C}\right)$ microorganisms give way to psychrophilic $\left(<10^{\circ} \mathrm{C}\right)$ microbial taxa. A concomitant change is evident in invertebrate biodiversity and community structure, as habitat-endemic, symbiotrophic invertebrates and associated macrofauna dominant at active vents die-off at waning vents and are absent at inactive sulfides (Van Dover, 2000, 2011; Figure 1). Active sulfide ecosystems have been the subject of considerable research since their initial discovery in 1977 (Godet et al., 2011; Van Dover et al., 2018), but inactive sulfide ecosystems have not received anywhere near as much scholarship to date, particularly with regard to the invertebrate assemblages that they might host. Given mineral exploitation interests (Ecorys., 2014) and international obligations call for protection and preservation of the marine environment, including the United Nations Law of the Sea Convention (Part XII, Article 192) and Sustainable Development Goal 14 adopted by United Nations Member States to conserve and sustainably use oceans, seas, and marine resources (UN News Centre, 2015), it is timely to review the current state of knowledge regarding ecosystems associated with inactive sulfide ecosystems and to identify key issues in environmental management.

\section{CHARACTERIZATION OF INACTIVE SULFIDES}

\section{Terminology}

Extinct, fossil(ized), inactive (also non-active), relict, dead, completed, quiescent, dormant. These are some of the adjectives used in the literature of the past four decades to describe deep-sea sulfide systems where hydrothermal fluid flux and constructive precipitation of minerals has ceased (or at least is no longer visually evident) and where living, endemic, symbiotrophic fauna that rely on chemoautotrophic primary production are absent (or very nearly so; see Symbiotrophic Invertebrates Associated With Inactive Sulfides below). The authoritative InterRidge Vents Database (Beaulieu and Szafranski, 2018) classifies all known and inferred deep-sea vents as either 'active' or 'inactive', as do recent publications by geologists (for example, Petersen et al., 2018), without explicit reference to the presence or absence of sulfide minerals. It is possible for active and inactive vents to occur without sulfide deposition, as was the case for the first deep-sea vents ever discovered [e.g., Garden of Eden (active vent) and Clambake (inactive vent) on the Galapagos Spreading Center (Corliss et al., 1979)]. At these vents, low-temperature fluids rich in dissolved sulfide (but without high concentrations of metals) emanated from cracks in the basalt crust. The term "inactive" is also occasionally used in reference to hard substrata or sediments where there is neither hydrothermal activity nor massive sulfide occurrences (e.g., Limén et al., 2006; Levin et al., 2009). Discussion is restricted here to studies of inactive sulfides that had once been active, and not sediment or rock where no evidence of past sulfide deposition is provided.

Of the adjectives in use, 'inactive' arguably makes the fewest assumptions about the age of a sulfide occurrence, about whether or not hydrothermal activity may recommence, or if the mineralogy has been modified by secondary reactions; inactive is the adjective adopted in this review. Even so, the concept of an 'inactive sulfide' (and of most of its synonyms) as used here and in the peer-reviewed literature encompasses a continuum of conditions, from 'inactive' sulfide chimneys or chimlets situated on the shoulders of belching $350^{\circ} \mathrm{C}$ black smokers (herein referred to as 'sulfide complexes'; Figure 1A) or surrounded by diffuse low-temperature flows, to cold sulfide aprons of active black smoker complexes, to sulfide chimneys, blocks, clasts, breccia, and stockworks that are no longer in proximity to or otherwise linked with active hydrothermal conduits and that may be buried beneath 10's of meters of sediment or within the rocks of the seafloor. A continuum of massive sulfide classifications, together with geological settings where they are typically found, ecosystem briefs, and high-level environmental management considerations, is summarized in Table 1. This continuum captures a multitude of mineralogical, microbial, and metazoan diversity and of successional sequences that are only beginning to be described. Arguably, active vents are also part of the continuum, initiating the cycle as nascent exhalations with little or no accumulated sulfide minerals following seafloor volcanic eruptions evolving to waning vent fields with declining fluid flux and dying populations of invertebrates hosting chemoautotrophic symbionts. Failure to acknowledge the mutable nature of deep-sea sulfide systemsin this review and elsewhere-carries with it the risk of oversimplifying the habitat.

To complicate matters, a sulfide occurrence initially described as inactive may subsequently be discovered on further exploration to include active hydrothermal vents, as was the case for the Duanqiao field on the Southwest Indian Ridge. Duanqiao $\left(50^{\circ} 24^{\prime} \mathrm{E}\right.$, SW Indian Ridge). Duanqiao was first thought to be inactive or at least to be at a very late stage of hydrothermal activity (Tao et al., 2014), but during a 2015 expedition, a large sulfide edifice with weak fluid flow was discovered that was colonized by populations of vent-endemic taxa, including scaly footed gastropods, mussels, and stalked barnacles (Zhou et al., 2018). Even with this new information, it is still not clear if Duanqiao might best be described as a sulfide complex 

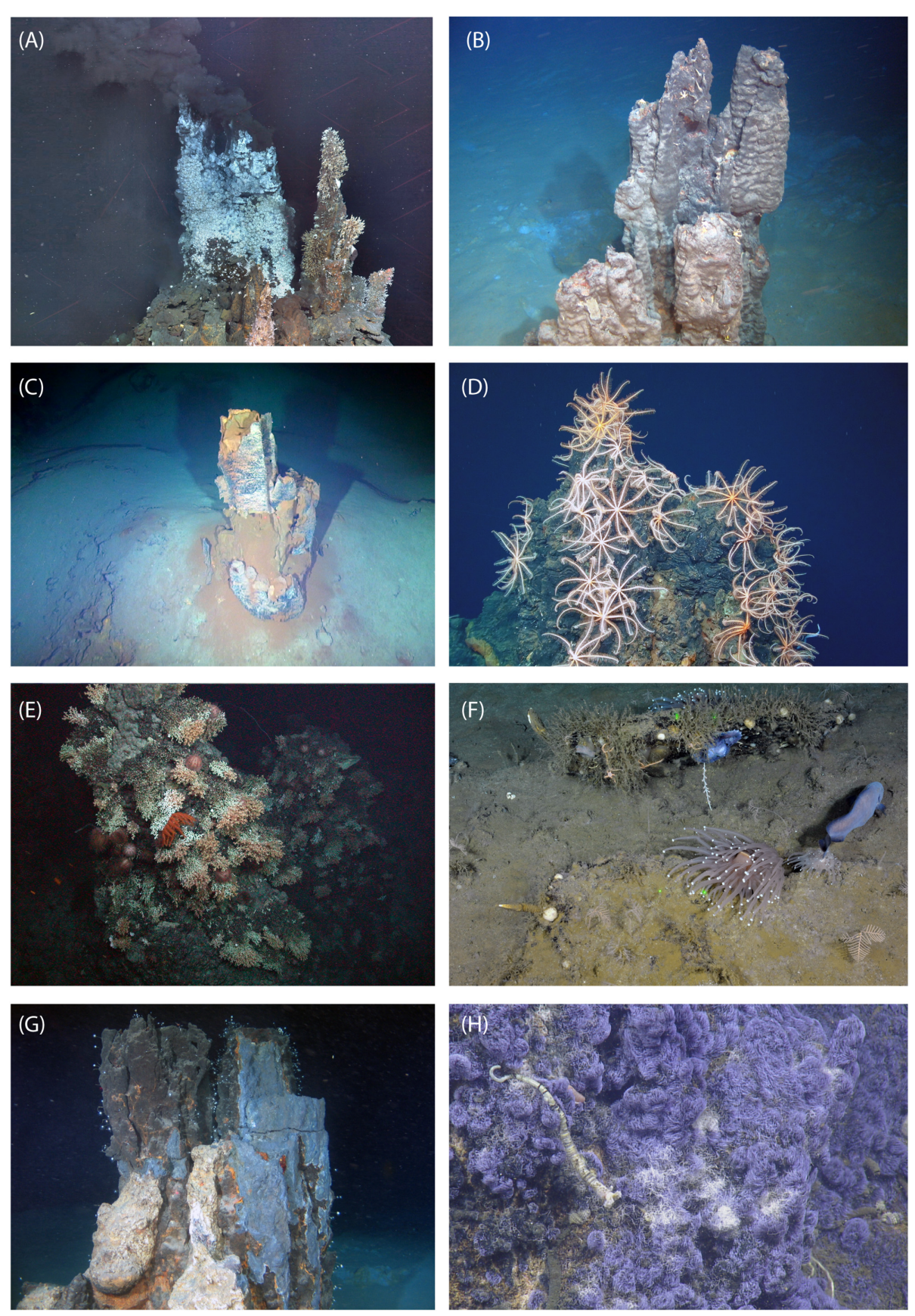

FIGURE 1 | Inactive sulfide ecosystems: examples providing a glimpse of the variety of megafaunal invertebrate characteristics to be found on sulfides, including absence of fauna, abundant suspension-feeding brisingid seastars, coral gardens with diverse feeding guilds, and dense carpets of folliculinid ciliates. (A) E9 mosaic (East Scotia Ridge; Marsh et al., 2012): an active (left)-inactive (right) "sulfide complex"; active chimney dominated by the yeti crab (Kiwa tyleri) with limpets (Lepetodrilus n. sp.) on their backs, inactive chimney Vulcanolepas scotiaensis (plus a few actinostolid anemones and the occasional K. tyleri); mosaic by L. Marsh, courtesy Jon Copley, National Oceanography Centre and the University of Southampton. (B) Manus Basin (SE Pacific; Erickson et al., 2009): inactive sulfide chimney on sediment, with barnacles, shrimp, courtesy Nautilus Minerals Niuguini Ltd. (C) "New Mound," TAG Hydrothermal Field (Mid-Atlantic Ridge; modified from Petersen et al., 2018), courtesy Bram Murton, National Oceanography Centre and Natural Environment Research Council. (D) Pito Seamount (SE Pacific) inactive chimney with brisingid seastars, courtesy Mike Cheadle, Barbara John, University of Wyoming. (E) Kermadec Arc (modified from Boschen et al., 2016): inactive sulfide with a coral- and urchin-dominated assemblage, courtesy of Rachel Boschen-Rose (Seascape Consultants), Malcolm Clark (NIWA), Ashley Rowden, (NIWA) and Neptune Minerals Inc. (F) Middle Valley (Juan de Fuca Ridge): inactive sulfide chimney fragment and sediment-dusted sulfide, with a diverse invertebrate assemblage including stalked barnacles, brooding octopods, corals, anemones, sponges, tunicates, hydroids, fish, courtesy Verena Tunnicliffe, University of Victoria. (G) Manus Basin (SE Pacific; Collins et al., 2012) inactive sulfide chimney with "Iollipop sponges" (carnivorous sponges in the family Cladorhizidae), courtesy Nautilus Minerals Niuguini Ltd. (H) Northern Guaymas Basin: inactive sulfide with folliculinid ciliates in blue tubes; a siboglinid worm in the image suggests the sulfide was recently hydrothermally active or perhaps even continues to flow very weakly; with permission (modified from Soule et al., 2018). 
or as a hydrothermal field comprising active and inactive sulfide occurrences.

The peer-reviewed literature on deep-sea hydrothermal systems is often casual in its use of the term 'deposit.' Throughout this review, use of the terms 'sulfide deposit' or simply 'deposit' is restricted to contexts referencing potential ore deposits on the seafloor that accumulate minerals in such quantities that they may be technologically reasonable to mine and economically profitable (Haldar, 2013). An area of $>100 \mathrm{~m}^{2}$ has been used as an operational definition of a (potential) deposit (Hannington et al., 2011). It follows, then, that a sulfide chimney is not itself a deposit, despite the fact that sulfide minerals were deposited to form the chimney. 'Massive' sulfide is used here in the sense that a sulfide rock is composed of at least $60 \%$ sulfide minerals (Franklin et al., 1981). A very small sulfide rock from a hydrothermal vent chimney in the deep sea is likely to be 'massive.' Because the focus of this review is ecological, use of the term 'inactive sulfide' should be taken to encompass both the biological community of interacting organisms and their physical environment.

\section{Initial Discoveries}

The first inactive deep-sea hydrothermal sulfides to be recognized in the literature arguably were the ophiolitic massive sulfide ore deposits of the Troodos Massif in Cyprus (Parmentier and Spooner, 1978 and papers cited therein) and the Kosaka deposits in Japan (reviewed by Tornos et al., 2015). Though long since uplifted onto land, these deposits were deduced to have formed at hydrothermal discharge zones at the interface of seabed and seawater. Massive sulfide ores of the Troodos have been of economic importance since at least the time of the Phoenicians, an observation that underscored early speculations about and current interest in the economic potential of sulfide deposits on the modern seafloor (Bischoff et al., 1983; Monecke et al., 2016; Petersen et al., 2016a, 2018).

Earliest observations of inactive massive sulfides in situ were made in 1978 during the CYAMEX Expedition to $21^{\circ} \mathrm{N}$ on the East Pacific Rise (Francheteau et al., 1979), prior to the discovery of black smokers that are the active, constructive phase of deep-sea massive sulfide evolution (Spiess et al., 1980). The CYAMEX sulfides were recognized as the submarine phase of zinc- and copper-rich massive sulfide deposits associated with ophiolite complexes on land. In subsequent field investigations along a $20-\mathrm{km}$ segment of the East Pacific Rise near $13^{\circ} \mathrm{N}$, more inactive hydrothermal sulfides $(\mathrm{x} 4)$ were observed than active sulfide systems (Hekinian et al., 1983). Inactive sulfides reported for the first time for off-axis $(6-18 \mathrm{~km})$ seamounts during the CYAMEX expedition were described as more abundant and more continuous than those on the ridge axis (Hekinian et al., 1983).

Despite the observed prevalence of inactive sulfide occurrences on the East Pacific Rise and elsewhere (Tao et al., 2012; Jamieson et al., 2014; Petersen et al., 2017), $\sim 75 \%$ of vent sites in the InterRidge database are listed as active (Petersen et al., 2018). This largely reflects exploration strategies during the past decades that favored prospecting for active hydrothermal systems by tracing water-column signatures of hydrothermal plumes to their source within or very close to neovolcanic zones (Baker and German, 2013). The largest and most commercially important deposits are expected to be preserved as inactive sulfides in off-axis regions, having formed either in place or having been transported away from the axis by seafloor spreading (Andersen et al., 2017).

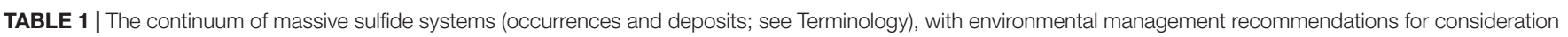
within the Area Beyond National Jurisdiction.

\begin{tabular}{|c|c|c|c|}
\hline Sulfide classification & Location & Ecosystem brief & $\begin{array}{l}\text { Recommended management } \\
\text { actions }\end{array}$ \\
\hline Active occurrences & Typical of fast-spreading centers & $\begin{array}{l}\text { Ephemeral (decadal scale) habitats, } \\
\text { with endemic taxa adapted to the } \\
\text { hydrothermal environment }\end{array}$ & $\begin{array}{l}\text { None at present - minerals generally } \\
\text { considered to be of no commercial } \\
\text { value (accumulations too small) } \\
\text { (Petersen et al., 2016b) }\end{array}$ \\
\hline Inactive occurrences & Typical of fast-spreading centers & $\begin{array}{l}\text { Ephemeral (decadal scale) habitats, } \\
\text { without endemic taxa adapted to the } \\
\text { hydrothermal environment }\end{array}$ & $\begin{array}{l}\text { None at present - minerals generally } \\
\text { considered to be of no commercial } \\
\text { value (accumulations too small) } \\
\text { (Petersen et al., 2016b) }\end{array}$ \\
\hline $\begin{array}{l}\text { Potential active deposits includes } \\
\text { active sulfide ecosystems and } \\
\text { active/inactive sulfide complex } \\
\text { ecosystems }\end{array}$ & $\begin{array}{l}\text { Most likely at intermediate, slow, and } \\
\text { ultraslow spreading centers, and some } \\
\text { seamounts }\end{array}$ & $\begin{array}{l}\text { Persistent (millennial + scale) habitats, } \\
\text { with endemic taxa adapted to the } \\
\text { hydrothermal environment }\end{array}$ & $\begin{array}{l}\text { Protect from mining and impacts of } \\
\text { mining activities; baseline studies and } \\
\text { monitoring essential, if in close } \\
\text { proximity to a discrete inactive deposit } \\
\text { (i.e., potentially subject to indirect } \\
\text { impacts from mining activities) (Van } \\
\text { Dover et al., 2018) }\end{array}$ \\
\hline $\begin{array}{l}\text { Potential inactive deposits may be } \\
\text { near- or far-field (relative to active } \\
\text { deposits) and/or sediment-covered }\end{array}$ & $\begin{array}{l}\text { Most likely at intermediate, slow, and } \\
\text { ultraslow spreading centers, off-axis of } \\
\text { these spreading centers, and some } \\
\text { seamounts }\end{array}$ & $\begin{array}{l}\text { Persistent (millennial + scale) habitats; } \\
\text { often colonized by suspension-feeding } \\
\text { and microcarnivorous invertebrates, } \\
\text { possibly colonized by specialist taxa } \\
\text { but so far this remains speculation }\end{array}$ & $\begin{array}{l}\text { Baseline studies essential (ISA, 2010); } \\
\text { identify suitable PRZs, IRZs for } \\
\text { monitoring (ISA, 2018a); protect from } \\
\text { mining and impacts of mining activities } \\
\text { where deposits host vulnerable } \\
\text { ecosystems }\end{array}$ \\
\hline
\end{tabular}

PRZ, Preservation Reference Zone; IRZ, Impact Reference Zone. 


\section{Dimensions and Distributions of Inactive Sulfide Occurrences and Potential Sulfide Ore Deposits}

The CYAMEX "completed or quiescent" sulfide occurrences (Francheteau et al., 1979) on the East Pacific Rise were small, on the order of $10 \mathrm{~m}$ in height, $5 \mathrm{~m}$ in diameter, spaced 4$5 \mathrm{~m}$ apart for $50 \mathrm{~m}$ along the strike of the ridge axis. These dimensions have since proved to be characteristic of inactive sulfides on fast-spreading ridge axes, where both active and inactive sulfide occurrences are abundant but small due to the high frequency of volcanic eruptions that disrupt fluid flow and bury the sulfide chimneys and breccias (Hannington et al., 2011). Active and inactive sulfides may be interspersed within a local region (10's of meters) or isolated by 100's of meters or more. The small dimensions of inactive sulfides on fast-spreading ridge systems (8-12 $\mathrm{cm} \mathrm{yr}^{-1}$ full rate) seem to ensure that they are not targets for deep-sea mining (Petersen et al., 2017). However, large inactive sulfide occurrences are known 2- to 11-km off-axis from the fast-spreading East Pacific Rise (Fouquet et al., 1996). Ridge axes of intermediate spreading rate, such as the Galapagos and NE Pacific Ridges may host sizeable occurrences of sulfides, such as the inactive Galapagos Mounds (Embley et al., 1988) and sulfide mounds on Gorda Ridge (Zierenberg et al., 1993).

As currently understood, the largest potential sulfide deposits of commercial interest on the mid-ocean ridge system are found in tectonic settings of slow $\left(2-4 \mathrm{~cm} \mathrm{yr}^{-1}\right.$, full rate) and ultra-slow $\left(<2 \mathrm{~cm} \mathrm{yr}^{-1}\right)$ spreading centers, where deep-penetrating faults tap large heat reservoirs that can sustain hydrothermal activity for extended durations (McCaig et al., 2007; Hannington et al., 2011; German et al., 2016; Andersen et al., 2017). The TAG active hydrothermal system on the slow-spreading Mid-Atlantic Ridge is exemplary of the footprint of such a potential deposit, with a surface expression on the order of $200 \mathrm{~m}$ in diameter, a maximum elevation of $\sim 50-60 \mathrm{~m}$ above the surrounding seafloor (Rona et al., 1986; Humphris and Kleinrock, 1996). Numerous inactive sulfide mounds of similar and even somewhat larger dimensions (e.g., Mir Mound: 400-600 $\mathrm{m}$ in diameter) lie within the $\sim 5 \mathrm{~km}^{2}$ TAG Hydrothermal Field (Rona et al., 1993; Lehrmann et al., 2018), but are geographically isolated from the active mounds (at least at the surface). Other large sulfide accumulations may be found on intermediate spreading ridges as well as in island arc environments and marginal basins (Hannington and Monecke, 2009; Cherkashov, 2017). Where active hydrothermal 'districts' are found, there are typically more discrete inactive sulfide accumulations than active sulfide systems (Cherkashov et al., 2010; Jamieson et al., 2014; Copley et al., 2016). While most known inactive sulfides are exposed on sediment-starved ridge axes, inactive sulfide outcrops are also known from sedimenthosted ridges close to continental margins, e.g., the Bent Hill inactive sulfide mound (35-m high, 100-m wide) of Middle Valley on the Juan de Fuca Ridge (Goodfellow and Franklin, 1993).

\section{Prospecting for Potential Sulfide Ore Deposits}

With new suites of exploration technologies and approaches, large inactive sulfide occurrences are expected to be located up to a few 10's of $\mathrm{km}$ on either side of a ridge axis, which opens a tremendous area for prospecting (McCaig et al., 2007; Petersen et al., 2017; Peukert et al., 2018). High-resolution bathymetric mapping by autonomous underwater vehicles (AUVs) recently has been used to discover numerous exposed inactive sulfides, even in regions that had been already been extensively explored and mapped (Jamieson et al., 2014; Petersen et al., 2017). Investment is also being made in detailed geospatial analysis of geological features to develop probabilistic maps of favorable prospective regions of mid-ocean ridges (Ren et al., 2016; Juliani and Ellefmo, 2018). New seismic (Asakawa et al., 2018) and electromagnetic (Schwalenberg et al., 2016; Müller et al., 2018; Safipour et al., 2018) tools are being developed and tested to detect sulfides in the absence of physico-chemical water column anomalies, even when buried beneath 10 's of meters of sediment. Future avenues of sub-sediment exploration may include gravity coring and shipboard analysis of metals in sediments together with AUV-based self-potential, electromagnetic, hyperspectral, and bathymetric mapping that might be used to locate sulfides as much as 20-km off-axis (Petersen et al., 2017, 2018; Dumke et al., 2018).

\section{Sulfide Mineralogy}

Microbial distributions and metabolic pathways are linked to sulfide mineralogy and thus mineralogy must be considered in studies of microbial communities and metazoans associated with inactive sulfides. Massive sulfides recovered from active hydrothermal vents on the seafloor include pyrrhotite, pyrite/marcasite, sphalerite/wurtzite, chalcopyrite, bornite, isocubanite, barite, anhydrite, and amorphous silica. The chemical composition is highly variable (Petersen et al., 2016a), but in some places $\mathrm{Cu}$ and $\mathrm{Zn}$ concentrations can be comparable to those found in terrestrial massive sulfide deposits (Herzig and Hannington, 1995). Metal content (Ag, $\mathrm{Au}, \mathrm{Ba}, \mathrm{Cu}, \mathrm{Pb}, \mathrm{Sb}$, $\mathrm{Zn}$ ) of massive sulfides from hydrothermal settings associated with volcanic arcs is greater than that of massive sulfides from mid-ocean ridge settings (Rona, 2008).

Abiotic weathering (oxidation, corrosion) alters the mineral composition of massive sulfides (Hannington, 1993), and, where hydrothermal activity is intermittent over thousands or tens of thousands of years, secondary mineralization and zone refining can take place (Lehrmann et al., 2018). Some sites will be more predisposed to oxidative weathering than others, due to their mineralogy and/or environmental conditions, and certain sites may have a greater potential for metal dissolution under natural conditions (Fallon et al., 2017, 2018). The mineralogical character and weathering conditions can affect the diagenetic sequence and commercial quality of a potential deposit (Melekestseva et al., 2018), as well as the structure and function of associated ecosystems in ways that we do not yet fully understand.

It is beyond the scope of this review to provide a detailed summary of the diverse mineralogies of and abiotic weathering processes associated with inactive sulfides on midocean ridges, in back-arc basins, or off-axis submarine volcanoes. Competent reviews and studies may be found in, for example, Herzig and Hannington (1995), Lehrmann et al. (2018), and Popoola et al. (2019). 
While massive sulfides are characteristic products of seabed hydrothermal activity, not all structures associated with hydrothermal venting are massive sulfides. For example, silica $\left(\mathrm{SiO}_{2}\right)$ chimney fields are reported from the Galapagos Spreading Center (Herzig et al., 1988), barite $\left(\mathrm{BaSO}_{4}\right)$ chimneys from the Arctic Mid-Ocean Ridge (Steen et al., 2016), and carbonate structures from the Mid-Atlantic Ridge (Kelley et al., 2005).

\section{MICROBIOLOGY OF INACTIVE SULFIDES}

\section{Early Studies}

Study of microbial diversity and processes associated with inactive sulfides lagged behind descriptive and experimental studies of the microbial ecology of active hydrothermal vent ecosystems (Karl et al., 1980) by more than a decade. Microbiologists were first motivated to study microbial communities on metal sulfides (Wirsen et al., 1993; Edwards et al., 2003a) because morphological characteristics of the feeding appendages and gut contents of the dominant invertebrate (shrimp) at the TAG hydrothermal site on the Mid-Atlantic Ridge suggested ingestion of a microbially enriched substratum (Van Dover et al., 1988). An early account of pyrite $\left(\mathrm{FeS}_{2}\right)$ associated chemolithoautotrophic microbes that oxidize sulfide noted that polymetallic sulfides can serve as a "stable source of electrons for chemosynthetic production of organic carbon in the deep sea" long after hydrothermal activity ceases (Eberhard et al., 1995), a point that has since been underscored by others (McCollom, 2000; Edwards, 2004; Edwards et al., 2005; Kato et al., 2015; Nakamura and Takai, 2015; Kato and Yamagishi, 2016).

Further characterization of chemoautotrophic endolithic (rock-hosted) bacteria and their role in sulfide weathering under ambient low-temperature $\left(3-4^{\circ} \mathrm{C}\right)$ incubation studies demonstrated that neutrophilic iron-oxidizing bacteria can mediate formation of iron oxide minerals (Edwards et al., 2003a). Bacterial isolates from polymetallic sulfides belong to phylogenetically diverse groups of $\alpha$ - and $\gamma$-Proteobacteria, and are microaerophilic (2-10\% $\mathrm{O}_{2}$ ), neutrophilic ( $\mathrm{pH}$ 6.5-7.5), obligate chemoautolithotrophs that gain metabolic energy from oxidation of iron associated with sulfide rock (such as pyrite) as well as with basalt (which is about $\sim 10 \% \mathrm{FeO}$ ) (Edwards et al., 2003b). These and more recent studies (e.g., Barco et al., 2017; Meier et al., 2018) confirm that iron-oxidizing bacteria can be abundant on inactive sulfides and establish likely linkages among bacterial populations, sulfide weathering and dissolution of metals, and the carbon cycle (Edwards et al., 2004; Li et al., 2017).

\section{Microbial Succession Following Cessation of Vent Activity}

Microbial community structure changes dramatically when hydrothermal activity ceases and the microbial system shifts from exploiting energy supplied from the chemical disequilibrium between seawater and hydrothermal fluids to sulfide weathering and decomposition of organic remains (Suzuki et al., 2004; Kato et al., 2010; Sylvan et al., 2012; Li et al., 2017;
Christakis et al., 2018). Microbial communities from inactive sulfides are 'decidedly different' from communities reported from hydrothermally active sulfides, even when active and inactive sulfides are separated by only a few meters (Suzuki et al., 2004). Similar findings have emerged from more recent study of active and inactive sulfides from diverse geographic settings (Toner et al., 2013; Li et al., 2017; Christakis et al., 2018; Meier et al., 2018).

During the successional sequence of a sulfide transitioning from a constructional phase to a weathering phase, initial microbial colonizers may be aerobic sulfur oxidizers (Edwards et al., 2003a) that produce iron oxyhydroxide crusts ("gossans"), with a shift from autotrophic bacteria to bacterial populations that may take advantage of enriched organic carbon from both decomposition products and new (autotrophic) growth ( $\mathrm{Li}$ et al., 2017). Taxa potentially involved in ammonia oxidation are also reported from inactive sulfides (Suzuki et al., 2004; Kato et al., 2010; Christakis et al., 2018). Where archaea are found, they are inferred to be remains of archaea hosted by the sulfide when it was bathed in hydrothermal fluids rather than active populations, due to unfavorable conditions for archaeal growth, including low temperatures (Li et al., 2017). Mesophilic and thermophilic archaea, which are relatively common in sulfide samples from hydrothermally active sulfides (Schrenk et al., 2003), make up at most only a few percent of the total microbial assemblage in inactive sulfide samples (Rogers et al., 2003; Suzuki et al., 2004; Edwards et al., 2005; Kato and Yamagishi, 2015). While archaea are generally minor components of the microbial communities of inactive sulfides, Euryarchaeota dominated in relatively more-oxidized inactive sulfide samples from the Kairei vent field (Indian Ocean), suggesting that they may succeed as early colonizers in the successional sequence (Suzuki et al., 2004).

Once oxide crusts form, iron-oxidizing bacteria can become established under their preferred microaerobic conditions (Rogers et al., 2003; Li et al., 2017). The degree to which inactive sulfides are exposed to oxygenated seawater or capped with impermeable crusts of iron oxyhydroxides (Toner et al., 2016) at the seafloor or siliceous jasper below the sediment (Lehrmann et al., 2018) is an important determinant of the distribution of microbial functional types and potential alteration products. Colonization experiments show that a simple metric like bacterial colonization density can be related to mineral type, with bacterial density decreasing according to the following mineral sequence: elemental sulfur $>$ chimney sulfide $>$ marcasite $>$ pyrite $>$ sphalerite $>$ chalcopyrite (Edwards et al., 2003a).

An example of the shift in relative abundance of metabolic types from active and inactive sulfides is provided in Table 2. $\varepsilon$-Proteobacteria, which dominate the bacterial community associated with polymetallic sulfides at active vents (Kato et al., 2010; Christakis et al., 2018), tend not to be detected in hydrothermally inactive sulfide samples (Zhang et al., 2016) or to be minor components of clone libraries (Kato et al., 2010; Sylvan et al., 2012). Members of the Aquificae [anaerobic, thermophilic, chemoautotrophic], also common at active vents (Nakagawa and Takai, 2008), were not detected in inactive sulfides (Sylvan et al., 2012) or were in very low abundance (Christakis et al., 2018). 
TABLE 2 | Shifts in potentially dominant ecological roles for microbial taxa comprising $\geq 1 \%$ of Illumina sequences for active and inactive sulfide samples from the Kolumbo submarine volcano (Hellenic Volcanic Arc).

\begin{tabular}{llcc}
\hline $\begin{array}{l}\text { Potential ecological } \\
\text { role }\end{array}$ & Taxon & $\begin{array}{c}\text { Active } \\
\mathbf{( \% )}\end{array}$ & $\begin{array}{c}\text { Inactive } \\
\mathbf{( \% )}\end{array}$ \\
\hline $\begin{array}{l}\text { Sulfur oxidation } \\
\text { Nitrate reduction }\end{array}$ & $\begin{array}{l}\text { E-Proteobacteria } \\
\text { E-Proteobacteria }\end{array}$ & 22.6 & 1.6 \\
Thermophiles, & Thermotogae, & 17.4 & 1 \\
hyperthermophiles & Deinococcus & & $<1$ \\
Sulfur respiration & Crenarchaeota & 8.4 & $<1$ \\
Hydrogen oxidation & Aquificae & 7.6 & $<1$ \\
Sulfate reduction & $\delta$-Proteobacteria & 5.2 & 2.6 \\
Denitrification & $\varepsilon$-Proteobacteria & 5.1 & $<1$ \\
Sulfur reduction & Aquificae & 2.9 & $<1$ \\
Sulfur oxidation & $\gamma$-Proteobacteria & 2.3 & 5 \\
Ammonia oxidation & Thaumarchaeota & $<1$ & 8.6 \\
Nitrite oxidation & $\delta$-Proteobacteria & $<1$ & 1.7 \\
Sulfur oxidation & $\alpha$-Proteobacteria & $<1$ & 1.7 \\
Methane oxidation & $\gamma$-Proteobacteria & $<1$ & 1.2 \\
Nitrogen fixation & $\alpha$-Proteobacteria & $<1$ & 1.1 \\
\hline From Christakis & & &
\end{tabular}

From Christakis et al. (2018).

There is also indication from lipid biomarker studies that the dominant microbial carbon fixation pathway shifts from reverse Tricarboxylic Acid (rTCA) in active sulfides to Calvin-BensonBassham (CBB) in inactive sulfides (Reeves et al., 2014).

Microbial communities of inactive sulfides from Manus Basin allied with groups that are widespread and abundant in marine sediments and were classified into two types, one dominated by anaerobic, autotrophic sulfate reducers, the other by aerobic sulfide-oxidizing autotrophic $\gamma$-Proteobacteria (Meier et al., 2018). The distribution of these two groups was independent of age of the sulfide (from $\sim 0$ to more than $\sim 3000$ years). Kato and Yamagishi (2015) recently classified microbial communities of inactive sulfides from the East Pacific Rise, Indian Ridge, and Southern Mariana Trough into three categories based on dominant bacterial groups: (i) where $\varepsilon$-Proteobacteria are relatively abundant; inferred to represent an early stage in the thermal and oxidative state of the sulfides or to be remnants of former hydrothermal activity grouping with communities from active sulfides, (ii) where $\gamma$-Proteobacteria are relatively abundant, and (iii) where Bacteroidetes (including fermenters) and Nitrospirae (including metal reducers) are relatively abundant.

Within inactive sulfides, magnetotactic bacteria allied to Magnetobacterium bavaricum (Nitrospirae) have been found in high abundance at what is presumed to be the redox interface between oxidative seawater infiltration and unoxidized metal sulfides, suggesting that these bacteria may use iron or sulfur metabolic pathways (Suzuki et al., 2004; Edwards et al., 2005). Magnetotactic bacteria may thus also be important in the biogeochemical cycles of iron and sulfur (Lin et al., 2014). Subsequent studies have detected bacteria allied to M. bavaricum in samples from inactive sulfides on the East Pacific Rise (Sylvan et al., 2012), and a draft genome of a related species in the genus suggests the potential for an autotrophic lifestyle using the Wood-Ljungdahl pathway for $\mathrm{CO}_{2}$ fixation.

Occasionally, microbial communities of inactive sulfides may be visually conspicuous, colonized by macroscopic, filamentous bacteria that likely play a role in the sulfur cycle, either as sulfur oxidizers or sulfate reducers. 'Cotton-like' mats on inactive sulfide chimneys of the Southern Mariana Trough included a dominant clone belonging to the family Desulfobulbaceae ( $\delta$-Proteobacteria), with $99 \%$ sequence similarity to large bacterial filaments from active vents on the Central Indian Ridge (Kato and Yamagishi, 2016). Intriguingly, these filamentous bacteria have recently been hypothesized to be 'cable bacteria' that harvest and transport electron donors and electron receptors from widely separated zones (bridging centimeters) using electrical currents (Meysman, 2018).

The role of metazoans in the weathering process and successional stages of sulfide microbial communities is rarely discussed. Where there may be invertebrate (and fish) grazers on microbial growth or other styles of animal exploitation of inactive sulfide surfaces, microbial diversity and productivity likely respond to physical disturbances that generate enhanced and/or more prolonged exposure to oxygen and microhabitat gradients that increase heterogeneity and microbial diversity (Edwards, 2004).

\section{Microbial Diversity, Abundance, and Activity}

Enhanced microbial diversity on inactive sulfides is attributed to the heterogenous and evolving physical, chemical, and mineralogical characters of the substratum (Christakis et al., 2018), and ${ }^{13} \mathrm{C}$-depleted carbon isotopic compositions of organic material in inactive sulfides are consistent with chemolithoautotrophic carbon fixation (Kato et al., 2010). In at least one instance, the diversity of the microbial community decreased with increased degree of weathering (Rogers et al., 2003). Theoretical (McCollom, 2000; Edwards et al., 2003a) and empirical studies indicate that abundance and activity of microbial communities at inactive sulfides may be comparable to or even greater than that of active sulfides (Kato et al., 2010; Li et al., 2017). Cell densities of inactive sulfides may be on the order of $10^{7}$ to $10^{9}$ cells gm $^{-1}$ and in the range observed at active chimneys (Suzuki et al., 2004; Kato et al., 2010, 2015; Sylvan et al., 2012). Total organic carbon (TOC) on exterior surfaces of inactive chimneys in the Mariana Trough may be up to five times the TOC on the exterior surface of active sulfides, consistent with high microbial productivity on inactive sulfides (Kato et al., 2010; Li et al., 2017). Despite this evidence, others posit that microbial activities are likely to be low (Le Bris et al., 2019). While the potential for microbial activity on metal sulfides is evident, metagenomic surveys and TOC measures are not sufficient tools to assess metabolic activity, including carbon fixation rates, on inactive sulfides (Olins et al., 2013; Le Bris et al., 2019). Experiments involving incubations at in situ temperatures, pressures, and mineralogical conditions, together with methods of measuring incorporation of labeled substrates, remain challenging to undertake in the deep sea. 
Bacteria and archaea of inactive sulfides are inferred to have metabolic potential for nitrogen (nitrogen fixation, ammonia oxidation, denitrification) and methane cycling, in addition to iron and sulfide oxidation (Zhang et al., 2016; Li et al., 2017). More than $25 \%$ of the OTUs of inactive sulfides samples from $9 \mathrm{~N}$ on the East Pacific Rise were related to lineages involved in sulfur, nitrogen, iron, and methane cycles (Sylvan et al., 2012). Autotrophic sulfide-oxidizing microbes related to siboglinid symbiont and Woeseiaceae-related clades of the $\gamma$-Proteobacteria have been found in inactive sulfides and may be mediators of sulfide weathering (Meier et al., 2018). Microbes associated with inactive (and active) sulfides have also been implicated in enhancing both bioleaching of potentially toxic metals ( $\mathrm{Fe}, \mathrm{Cu}$, $\mathrm{Zn}$ ) from sulfides and accelerating galvanic interactions that also increase metal dissolution rates (Fallon et al., 2017).

Iron-rich oxyhydroxide sediments associated with hydrothermal venting can also have a relatively high abundance of iron-oxidizing $\zeta$ (zeta)-Proteobacteria (Hoshino et al., 2016; McAllister et al., 2018) that may take the form of tube-like sheaths and twisted ribbon-like stalks, often localized in pits and pores (Edwards et al., 2003b; Edwards, 2004; Kato and Yamagishi, 2015). Iron transformation pathways in redox microenvironments ( $\mu \mathrm{m}$-scale) of inactive sulfides have abundant Fe-(III) reaction products, consistent with microbially mediated oxidation of S or Fe (Toner et al., 2016).

The extent to which microbial communities of subsurface sulfides may be similar to those of exposed sulfides is only beginning to be investigated. Microbial communities of inactive sulfides sampled in cores from beneath the seafloor were characterized by a large number of de novo bacterial OTUs and could be differentiated from the three putatively successional groups of Kato and Yamagishi (2015), as well as from those of active sulfides chimneys, iron-rich mats, manganese crust, and basalt (Kato et al., 2015). Subsurface sulfides had several microbial members in common with those of exposed inactive chimneys may comprise a 'core microbiome' of inactive sulfides, contributing to sulfur, iron, and carbon cycling (Kato et al., 2015). Newly published metabolic reconstructions of uncultivated bacteria in the phylum Nitrospirae and the class $\delta$-Proteobacteria (based on near-complete genomes) suggest potential for $\mathrm{CO}_{2}$ and nitrogen fixation as well as oxidation of $\mathrm{H}_{2}$, sulfide, and intermediate sulfur species in cold, dark, subseafloor sulfidehosted microbial ecosystems (Kato et al., 2018).

\section{A Rare Microbial Biosphere}

A study of microbial communities at the Kairei and Pelagia vent fields in the Indian Ocean supports the hypothesis that polymetallic sulfides of inactive vents host microorganisms not found elsewhere or detectable only in very low numbers (Han et al., 2018). Indeed, these inactive sulfide samples had more than $2.5 \mathrm{X}$ the number of OTUs detected in active sulfide samples from the same vent fields. In this study, 81,000 OTUs were identified from inactive sulfides that were not detected in active sulfide samples; more than 70,000 of these inactive sulfide OTUs were also absent from samples of the surrounding seawater, hydrothermal plume, and hydrothermal fluid. Many OTUs were rare (relative abundance $<0.1 \%$ of total community) and most (up to 99\%) were de novo OTUs of unknown metabolic capacity, making it difficult to predict the impact of mining on biogeochemical cycles. The authors expressed concern regarding loss of rare OTUs if mining of inactive sulfides is permitted, due to potential diminishment of the genetic reservoir, and concluded that removal of sulfides would likely alter microbial community structure and biogeochemical cycles locally, and possibly, more distantly (Han et al., 2018). But other studies suggest that microbial communities of inactive sulfides may be allied to those of non-hydrothermal seafloor environments, including sediments and rocks (Kato et al., 2010). It seems premature to make a definitive assessment of the vulnerability of the microbial genetic reservoir at this time. However, psychrophilic autotrophs and other psychrophilic metabolic types associated with inactive sulfides are potentially of importance to biotechnology, bioremediation, and our understanding of the metabolic menus exploited by life on Earth and potentially elsewhere (Van Dover, 2007).

\section{ANIMAL COMMUNITIES (OR ASSEMBLAGES) OF INACTIVE SULFIDES}

In the excitement of studying the strange biota adapted to extremes of chemistry and temperature of active hydrothermal vents (Baker et al., 2010), the animals of cold inactive sulfides have been all but ignored. Not all inactive sulfides are colonized by megafaunal animals (Figures 1A,B). Where megafauna have been observed, assemblages are most often comprised of taxa known from other hard substrata, that is, they are not endemic to or strictly dependent on the inactive sulfide habitat (Figures 1D-G). Observations and sampling of inactive sulfides for macrofaunal organisms (retained on a $0.3 \mathrm{~mm}$ sieve), and even smaller organisms, are scarce.

The substantial biomass at active sulfides is usually dominated by symbiotrophic invertebrate taxa that rely on chemoautotrophic bacteria for their nutrition. Such invertebratesymbiont associations are at present unknown from inactive sulfides and may not exist (though occasionally symbiotrophs that occur at active vents are found on what are described as inactive sulfides; see Section Symbiotrophic Invertebrates Associated With Inactive Sulfides). The magnitude and direction of linkages between the microbiology of inactive sulfides and animals colonizing the sulfides are unclear. It is conceivable that a host invertebrate might locally regulate the $\mathrm{pH}$ of sulfide rock to facilitate dissolution of the sulfide and acquisition of that sulfide for the nutrition of symbiotic bacteria (Van Dover, 2007), but such a scheme is imaginary at this point. While it also seems plausible that there exist assemblages of inter-dependent invertebrates and microbes characteristic of and possibly restricted to inactive sulfides environment (Van Dover, 2007), evidence of such an assemblage remains elusive. Sampling of the fauna of inactive sulfides has generally been through opportunistic, incidental efforts undertaken outside the scope of funded geological studies, which means there are many unknowns (but see Quantitative Ecological Studies of Inactive Sulfide Ecosystems). In this section, the limited 
knowledge of associations between invertebrate fauna and inactive sulfides is reviewed.

\section{Invertebrate Taxa So Far Only Known From Inactive Sulfides}

At least two limpet species (McLean, 1990) and one polynoid polychaete (Pettibone, 1989) have been described from inactive sulfides on the East Pacific Rise and Galapagos Spreading Center. Dozens of individuals of an undetermined ampharetid polychaete species (probably a species of Amphisamytha) were collected from an inactive chimney in the Longqi hydrothermal district on the Southwest Indian Ridge and proposed to be adapted to this environment (Zhou et al., 2018). To date, there remains no scientific case for exclusive fidelity of taxa only known from inactive sulfides to the inactive sulfide habitat, although the putative grazers (limpets) and deposit feeders (ampharetids) might plausibly be specialist consumers of heterotrophic or autotrophic microorganisms.

\section{Symbiotrophic Invertebrates Associated With Inactive Sulfides}

A "not uncommon" character of the fauna of inactive sulfides is the presence of taxa considered to be reliant on hydrothermal activity. At the inactive sulfides of the Pogomort sites $\left(13^{\circ} \mathrm{N}\right.$, East Pacific Rise), "empty tubes of alvinellids, dead vestimentiferans, serpulids, numerous small mytilids, turrid gastropods, patellids, pectinids, stalked barnacles, many crustaceans, including abundant galatheid squat lobsters (7 ind $\mathrm{m}^{-2}$ ), zoarcids, plus non-vent coelenterates, echinoderms" were reported, with the note that small mytilid mussels (Bathymodiolus thermophilus) occurred in "unexpected densities" (Fustec et al., 1987). Large bathymodiolin mussels (Bathymodiolus azoricus) have been reported from inactive chimneys of the PP37 complex of the Rainbow Hydrothermal Field, Mid-Atlantic Ridge (Desbruyères et al., 2001). In the Northern Guaymas Basin, "extinct sulfide mounds displayed dense mats of blue folliculinid ciliates," as well as "gastropods, scaleworms, some sessile polychaetes, deep-sea sponges, a few Escarpia tubeworms, and a third unidentified tubeworm species" (Figure 1H) (Soule et al., 2018). Elsewhere, blue mats of folliculinds are well known as peripheral taxa at active vents and to be symbiotic with bacteria (Kouris et al., 2007, 2010).

The simplest explanations for the occurrence of vent-endemic symbiotrophs on inactive sulfides include (i) very recent cessation of hydrothermal flow (to be followed by mortality of the symbiotrophs), (ii) diminution of fluid flow to a point where symbiotrophs can eke out a living but below detection without precision temperature and chemical measurements, and (iii) facultative nutrition [e.g., potential for dual trophic modes of suspension-feeding and symbiotrophy in mussels; Page et al., 1990]. Even facultative feeders are expected to succumb to nutritive stress if sufficiently distant from an adequate quantity or quality of food supply (Smith, 1985). Relicts of hydrothermal vent fauna (shells and tubes of symbiotroph taxa) are considered indicative of "recently" inactivated sulfides (e.g., Southwest Indian Ridge; Tao et al., 2012).

\section{Quantitative Ecological Studies of Inactive Sulfide Ecosystems}

At present, there are only a few published studies that quantitatively study ecological characteristics of inactive sulfide ecosystems, motivated by environmental baseline needs related to deep-sea mining. As will become evident in this section, many unknowns remain, including (i) whether the fauna of inactive sulfides is the same as-or a subset of-the fauna of other kinds of hard substrata (e.g., basalt, dacite) in the region, (ii) colonization, growth, and reproductive rates of suspension- and deposit-feeding taxa of inactive sulfides and the extent to which they are enhanced (or not) by chemosynthetic subsidies from active vents, and (iii) whether microbial autotrophic processes dependent on oxidation of mineral sulfides plays any role in the nutrition of the colonizing fauna.

\section{Manus Basin Inactive Sulfide Ecosystems}

The Solwara 1 hydrothermal field in Manus Basin (Papua New Guinea) is an area where active and inactive sulfide deposits are interspersed over an area of $\sim 1 \mathrm{~km} \times 0.5 \mathrm{~km}$ (1500-1650 m depth). Nautilus Minerals Niuguini Limited has held a license to mine the Solwara 1 Prospect in Manus Basin (Papua New Guniea) $^{1}$ since 2011, although at this time, any mining of Solwara 1 is on hold for lack of financial resources. As part of their environmental permit, Nautilus Minerals undertook an Environmental Impact Assessment (EIA)in the early-to-mid 2000's (Gwyther, 2008). This EIA included studies of fauna associated with inactive sulfides that are summarized here.

\section{Dietary sources}

While carbon isotopic compositions of the fauna associated with inactive sulfides at Solwara 1 could not be used to resolve chemosynthetic versus photosynthetic dietary sources, sulfur isotopic compositions indicated a dietary source of sulfur ultimately derived from sulfide of vent fluids through chemosynthesis rather than from seawater sulfate through photosynthesis (Erickson et al., 2009). Given that suspensionfeeding and micro-carnivorous invertebrates were the dominant feeding guild at the inactive sites and that active and inactive sulfides were in close proximity, the primary source of chemoautotrophic nutrition for the fauna on inactive sulfides at Solwara 1 was inferred to be suspended particulates/organisms produced at and delivered from nearby active vents. Elsewhere, particularly where inactive sites are located at some distance (100's of $\mathrm{m}$ ) from active sulfides, elevated biomass of suspension feeders associated with inactive chimneys may be due to hydrographic effects that concentrate food particles (Genin et al., 1986) and independent of autochthonous, chemoautotrophic production (Van Dover, 2007).

\section{Community (or assemblage) structure}

A comparative quantitative study of community structure on peripheral, inactive sulfide occurrences at the Solwara 1 Prospect and at South $\mathrm{Su}$, a proposed no-mine area, was undertaken in 2007 (Collins et al., 2012). Ninety-one

\footnotetext{
${ }^{1}$ http://www.canadianminingjournal.com/news/mining-lease-first-everunderwater-lease-granted-to-nautilus/ (accessed June 11, 2019).
} 
taxa were recovered from inactive sulfides at both sites. Although 11 taxa typically considered to be associated with active sulfides were included in this list, invertebrate taxa known to host chemoautotrophic endosymbionts were not found on inactive sulfides, with the exception of a single juvenile specimen of the hairy snail, Alviniconcha sp. Most taxa $(>80 \%)$ were represented by fewer than 5 specimens. Solwara 1 inactive sulfides were dominated by barnacles (Vulcanolepas cf. parensis), squat lobsters (Munidopsis spp.) hydroids, cladorhizid sponges (Abyssocladia dominalba) and/or bamboo corals (Keratoisis sp.) (Erickson et al., 2009; Collins et al., 2012). Faunas of active and inactive sulfides were different based on multivariate statistics (presence-absence data), but faunas of inactive sulfides at Solwara 1 and South $\mathrm{Su}$ could not be differentiated statistically.

\section{Population structure}

Genetic data and population structure can reveal the degree to which populations are connected. The genetic population structure of several taxa reported from inactive sulfides in Manus Basin (Collins et al., 2012) has been studied, but these taxa also occur at active sulfides, where it is relatively easy to collect the large sample sizes needed for such studies. These taxa include: a stalked barnacle [Vulcanolepas parensis; (Plouviez et al., 2013), a shrimp [Chorocaris sp. 2; (Thaler et al., 2014)], a squat lobster [Munidopsis lauensis; (Thaler et al., 2014)], and two limpets [Olgasolaris tollmani; (Thaler, 2012), Lepetodrilus aff schrolli; (LaBella, 2017)]. In addition, a juvenile specimen in the genus Alviniconcha was collected from inactive sulfide by Collins et al. (2012). In all of these taxa [including Alviniconcha sp. 2; (Suzuki et al., 2006)], analysis of mitochondrial Cytochrome Oxidase I (COI) sequences of individuals from sampled sites in Manus Basin are consistent with panmixia within the Basin, although microsatellite studies of Munidopsis lauensis population structure suggest that there are at least two genetically differentiated populations of this species in Manus Basin. Two other basins within the SW Pacific region (i.e., Fiji and Lau Basins) support different genetic populations of these predominantly ventassociated taxa, with the exception of Lepetodrilus aff schrolli (LaBella, 2017), which, based on COI sequences, appears to be panmictic across all three Basins. Population structure for inactive-sulfide-associated taxa not also occurring at vents is apparently as yet unknown.

\section{Sedimented sulfides}

The Solwara 1 Prospect includes soft sediment habitats that are likely influenced by hydrothermal fluids. But the macrofauna of sediment-hosted inactive hydrothermal systems are especially challenging to study, since reliable visible indicators of former activity are limited to shell beds or other predominantly inorganic remains that remain unburied by sedimentation. While characteristics of infaunal samples from inactive sediments of Solwara 1 and South $\mathrm{Su}$ have been reported (Levin et al., 2009), "inactive" in this case meant sediment cores collected $>50 \mathrm{~m}$ from active venting, without reference to any evidence of prior hydrothermal activity or sulfide minerals.

\section{Kermadec Volcanic Arc Inactive Sulfide Ecosystems}

Prospecting licenses have been awarded to Neptune Minerals Inc. for multiple areas along the Kermadec Volcanic Arc in the New Zealand Exclusive Economic Zone ${ }^{2}$. In an environmental baseline study of megafaunal distributions on hard substrata at three seamounts of the Kermadec Volcanic Arc, three lowdiversity assemblages of invertebrates dominated by comatulids, echiurans, or corals were associated with inactive sulfide occurrences (Boschen et al., 2015). While individual taxa in these groups also occurred on non-sulfide substrata in the region, the groupings of taxa within these inactive-sulfide assemblages were unique. At the Rumble II West seamount, coral (scleractinian)and urchin (Dermichinus horridus)-dominated assemblages were predominantly associated with inactive sulfide chimneys at the Proteus 1 proposed mine site, often in close proximity to active sulfides, but not all inactive chimneys were colonized by megafauna (Boschen et al., 2016). The abundance and biomass of these corals and urchins on the inactive sulfides was hypothesized to reflect access to productivity of the nearby active hydrothermal system (Boschen et al., 2016). Some corals observed on inactive sulfides at the Proteus 1 site may be at least 160 years old (Boschen et al., 2016).

\section{Lucky Strike and Kilo Moana Sulfide Complexes}

Lucky Strike, a vent field on the Mid-Atlantic Ridge south of the Azores, has been the subject of repeated study since the mid 1990s. The Eiffel Tower edifice is a sulfide complex that includes "inactive" sulfides classified as "Substratum 1a," colonized only by brachyuran crabs (Segonzacia mesatlantica) and hydroids (Cuvelier et al., 2009). According to the initial classification, this red-brown substratum (oxyhydroxide crust) has "no visible mineral precipitation and is unable to support vent-endemic fauna, probably because it is not permeable, i.e., no hot fluids can seep through. It can be present as small patches between the faunal assemblages or as larger patches further away from the fluid exits and nearly always at the base of the sulfide complex." Subsequent monitoring of the edifice revealed increasing percent cover of "Substratum 1a" (from <2\% in 1994 to $>8 \%$ in 2006 and 2008) and colonization by mussels (Bathymodiolus azoricus) with and without microbial mat on the shells (Cuvelier et al., 2011), consistent with (renewed) hydrothermal fluid flux. A similar transition from a patch of "inactive" sulfide to an active area with aggregations of symbiotrophic snails on the Kilo Moana 1C chimney complex (Lau Basin) was documented between visits in 2006 and 2009 (Sen et al., 2014). One take-away from these well-documented analyses is that complex edifices of active and inactive sulfide substrata are dynamic, and inactive surfaces may shift to active surfaces (and vice versa).

\section{Anecdotal Accounts of Faunal Assemblages on Inactive Sulfides}

Despite the paucity of quantitative biological data for inactive sulfides, there are many anecdotal reports of relatively high biomass of taxa that are common on hard substrata (e.g., basalt and other rocky outcrops) also occurring on sulfides, and other

\footnotetext{
${ }^{2}$ https://permits.nzpam.govt.nz/aca/
} 
reports where the absence of biotas on sulfides is noted. A nonexhaustive account of such anecdotal observations follows here.

\section{Eastern Pacific Settings}

From a single inactive sulfide chimney on the Explorer Ridge, a "majid crab (about $60 \mathrm{~cm}$ across), alcyonacean polyp corals, a gorgonian fan coral and poecilosclerid plume sponges" were documented in a photo (Tunnicliffe et al., 1986). At Gorda Ridge, aggregations of large solitary tunicates, brisingid seastars, crinoids, sponges, anemones, and brachiopods-all elements of local non-vent fauna (Carey, 1990) but in higher density-were reported on inactive sulfides (Van Dover et al., 1990). Populations of brachiopods remain unknown from modern active sulfide ecosystems, though they can dominate the fossil record of sulfides uplifted to land (Little and Vrijenhoek, 2003). At Pito Seamount, dozens of isolated inactive sulfides were covered with a few to a great many suspension-feeding brisingid seastars, and brisingids are also common on inactive sulfides of the East Pacific Rise (Van Dover, personal observation).

\section{Western Pacific Settings}

In Manus Basin, "concentrations of large gorgonians, actinians, hydroids, brisingids and siphonophores" were reported in association with inactive sulfide chimneys (Galkin, 1997). In Lau Basin, brisingid seastars, corals, and sponges were observed on inactive edifices and were interpreted to be a final stage of succession (Sen et al., 2014). Further, this assemblage was considered likely to parallel communities on basalt distant from active hydrothermalism (Sen et al., 2014).

\section{Indian Ocean Settings}

Inactive sulfide chimneys at Longqi on the Southwest Indian Ridge were colonized by occasional Munidopsis-type galatheids and sea anemones (Zhou et al., 2018). At massive sulfide occurrences at the Mt. Jourdanne sulfide field on the same ridge, "neither recent biological features nor any clamshell relicts were observed in the entire area" (Münch et al., 2001). Vent biota or remnants are reported absent at inactive sulfide chimneys of the MESO zone on the Central Indian Ridge, but no explicit mention is made of the presence or absence of other invertebrates (Münch et al., 1999). In contrast, beds of anemones are reported as occurring on inactive sulfides peripheral to active sulfides of the Kairei and Edmond fields on the Central Indian Ridge (Van Dover et al., 2001).

\section{Atlantic Settings}

At the Moytirra vent field on the Mid-Atlantic Ridge north of the Azores, Mag Mell is an edifice with inactive sulfide chimneys, where only mobile predators (zoarcid fish) were observed (Wheeler et al., 2013). Of the many inactive sulfide occurrences reported elsewhere for the Mid-Atlantic Ridge, there is little or no mention of biota (e.g., Rona et al., 1993; Krasnov et al., 1995; Lalou et al., 1998; Gablina et al., 2012; Bel'tenev et al., 2017).

In a class of its own is the reported association of Paleodictyon nodosum traces with inactive sulfide mounds at the TAG Hydrothermal Field (Rona et al., 2009). The identity of $P$. nodosum is still subject to speculation; it is interpreted to be either a burrow or a compressed form of hexactinellid sponge, but to date, protoplasm of the organism has not been collected. It is reported to occur in densities of more than 40 patterns $\mathrm{m}^{-2}$ "on a thin layer of light gray hemipelagic calcareous lutite that veneers fine-grained red metalliferous sediment on the margins of the Mir relict hydrothermal zone" but absent on sulfide substratum (Rona et al., 2009). It is the association of P. nodosum with the margins of the massive sulfides that is of relevance, since this distribution suggests a sphere of influence of the inactive sulfides that extends beyond the exposed massive sulfides. However, traces similar to those of Paleodictyon nodosum are reported from abyssal locations remote from inactive sulfides, including the manganese nodule beds of the Clarion-Clipperton Zone (Durden et al., 2017b). Systematic mapping of distributions of P. nodosum traces along transects away from inactive sulfides at the TAG Field is needed before association of this trace with inactive sulfide ecosystems can be confirmed or rejected.

\section{Arctic Settings}

Mohn's Treasure is described as an inactive sulfide area on the Mohn's Ridge in the Arctic Basin. The area was first discovered by chimney fragments collected in a rock dredge (Olsen et al., 2016). During a subsequent exploration cruise, no new information regarding the location or extent of exposed sulfides was reported (Ludvigsen et al., 2016). Quantitative surveys of biota document megafaunal distributions at Mohn's Treasure, including fields of crinoids on sediments and a variety of sponge morphotypes on hard substrata (Paulsen, 2017), but despite the extent of this survey work, the relationship between this benthic community and inactive sulfides remains elusive. Inactive sulfides are also reported Akkarsgogen, also known as Squid Forest (Pedersen et al., 2010), but the biology of these inactive sulfides remains undescribed.

\section{ENVIRONMENTAL MANAGEMENT CONSIDERATIONS AND KNOWLEDGE GAPS}

The International Seabed Authority (ISA), the competent regulatory body for seabed mineral resources in international waters, is engaged in developing regulations, standards, and guidelines for environmental management of seabed minerals in Area Beyond National Jurisdiction. The terminology and requirements of the ISA for environmental management, which can be found throughout the ISA website ${ }^{3}$, are adopted here.

Not all inactive sulfides are equal in terms of environmental management needs related to deep-sea mining (Table 1); regulators will need to consider management needs across the continuum of inactive sulfide settings. Where inactive sulfide occurrences are small and without commercial interest, as on the fast-spreading East Pacific Rise, no management action is required. Where inactive sulfides are conjoined with active sulfides (referred to herein as "sulfide complexes"), there is the potential that mining these inactive sulfides could cause serious harm to the active

\footnotetext{
${ }^{3}$ https://www.isa.org.jm/
} 
sulfide ecosystem (Van Dover et al., 2018). Wherever inactive sulfides are of sufficient size and quality to be of commercial interest, environmental impact assessment and environmental management and monitoring plans will be required of mining contractors (Durden et al., 2017a), allowing decision makers to assess whether adequate evidence exists to ensure that mining may be permitted without threat of serious harm to the environment (Levin et al., 2016).

\section{Mining Impacts on Inactive Sulfide Ecosystems}

Potential impacts of mining on seafloor massive sulfides have been reviewed in multiple published articles, including (Van Dover, 2011, 2014; Boschen et al., 2013; Levin et al., 2016; Van Dover et al., 2017; Jones et al., 2018; Niner et al., 2018; Orcutt et al., 2018; Weaver et al., 2018); only a précis is provided here. Open-pit mining of inactive sulfide deposits as proposed by contractors (e.g., Gwyther, 2008) will result in modification of seabed topography (from mound to pit) and thus of circulation patterns at small spatial scales of 10's meters or more horizontally and 10's of meters vertically. This will likely be a permanent effect at inactive sites, unless there are mitigation efforts to increase the ventilation of the pits or there is reactivation of hydrothermal fluid flow, mineral precipitation, and sulfide construction.

Mining of seafloor massive sulfides will involve an initial pulverization stage at the seabed to create a slurry that can be lifted to the surface in a riser pipe (Gwyther, 2008; Liu et al., 2016). This processing step will expose fresh sulfide surfaces (of both the bulk deposit and of fine particulate debris generated by pulverization) to ambient, oxygen-rich seawater. Abiotic oxidation of mineral sulfides at neutral $\mathrm{pH}$ forms soluble sulfate and insoluble metal-oxyhydroxides. In experimental studies, pyrite is protected from oxidation by galvanic effects, while chalcopyrite and sphalerite are preferentially oxidized (Knight et al., 2018). Enhanced oxidation of copper sulfides and copper dissolution in galvanic cells (as well as zinc, lead, and cadmium) during mining operations (Fallon et al., 2017; Knight et al., 2018), together with known toxic effects of soluble copper (Flemming and Trevors, 1989; Stohs and Bagchi, 1995; Simpson and Spadaro, 2016), suggest the potential for geochemical modification/degradation of the environment. The toxicity of sulfides differ from one place to another, depending on their geological setting, mineralogy, and crystalline texture (Fallon et al., 2019). Based on limited laboratory experiments, metal toxicity has been considered to be minor relative to the physical impacts of mining (Simpson and Spadaro, 2016; Knight et al., 2018), but this perspective does not take into account ecotoxicological effects in the pelagic environment, and empirical evidence in the field supporting this view is lacking.

Stimulation of heavy-metal metabolizing microbes by mining activities may affect element cycling in the deep sea, including increased concentrations of bioavailable metals and biologically mediated precipitation (Orcutt et al., 2018). Because inactive sulfides are not associated with high temperature and acidic fluids that mediate metal dissolution in active hydrothermal systems, they have been deemed likely to be more 'ecofriendly' in this regard than active sulfides as a target for mining (Fallon et al., 2017).

Sulfuric acid generation by abiotic sulfide oxidation during mining operations (acid mine drainage) seems unlikely to exceed the buffering capacity of seawater (Bilenker et al., 2016), though a contrary view suggests that in an open-pit mining scenario, there is potential for ponding and the possibility of local acidification and anoxia (Orcutt et al., 2018). Natural 'capping' of sulfide minerals by insoluble metals such as iron-oxyhydroxides through abiotic and biotic processes may be sufficiently rapid to serve as a passive mitigation action against acid mine drainage (Edwards, 2004). Active mitigation of a hypothetical oxygendepleted and acidic 'pond' or pit seems plausible through selective contouring during mining operations to ventilate the depression. This or other potential mitigating actions [e.g., capping with introduced materials (Orcutt et al., 2018)] must not do more harm to the environment than good. The operational scale, mineral complexity, and biological activity of inactive sulfide systems all indicate that assessment of the environmental risk and monitoring of dissolved metals and of metal burdens outside the direct impact zone will be important components of environmental management plans, if and when mining of inactive sulfides on the seafloor is permitted (Hauton et al., 2017).

Invertebrate populations that occupy mineable surfaces and that have limited (or no) mobility will be exterminated. Extermination seems an unlikely but not impossible fate of microbial taxa (see concerns of Han et al., 2018), which may benefit from freshly exposed surfaces and other modifications of microenvironments. Mining of the inactive sulfide habitat may decrease the total habitat available; less habitat (or habitat of poorer quality) implies decreased abundance and diversity (Fahrig, 2017). Recovery of fixed or sessile invertebrate taxa will depend on larval recruitment, which in turn may respond to the pit configuration and modified benthopelagic circulation; whether this will enhance or diminish recruitment may be site and species specific. Natural recovery of invertebrate populations at a mine site may be impossible if no exposed hard substrata remains, or of long duration-decades for long-lived, slowgrowing taxa such as corals-if dependent on recruitment from nearby populations (i.e., without intervention). An alternative that mining improves the quality of the residual, freshly exposed inactive sulfide habitat that may persist after mining is concluded - seems unlikely, but, given all of the unknowns and uncertainties about mining, it is impossible to dismiss this as an outcome at this time. If taxa endemic to the inactive sulfide habitat are discovered, then local recovery of those taxa may be impossible if no inactive sulfides of sufficient quality remains. The potential for cumulative effects of multiple mining events in a region further complicate efforts to quantify uncertainties and risks to the environment.

Test mining of inactive sulfides was undertaken by the Ministry of Economy, Trade and Industry (METI) and the Japan Oil, Gas and Metals National Corporation (JOGMEC) in 2017 off Okinawa $(1600 \mathrm{~m})$, providing the first opportunity of assessing environmental impacts (Ministry of Economy Trade and Industry, 2017). A record of baseline data collected in the region from 2008 to 2012 exists (Narita et al., 2015) 
and measures of environmental impacts assessed through a monitoring program undertaken during the test mining operations will be forthcoming.

\section{Application of a Precautionary Approach}

Where there is threat of serious harm to the marine environment, a precautionary approach should be adopted (Vanderzwaag, 2002). Such an approach underlies the use of area-based management tools to protect $30-50 \%$ of the seabed in the Area from mining activities (Lodge et al., 2014), but it does not address metrics that can be used to assess the threat of serious harm to inactive sulfide ecosystems on the seabed. The ISA precautionary approach currently focuses on setting aside large "no-mine" Areas of Particular Environmental Interest (APEIs) through the precedent set by the Regional Environmental Management Plan (REMP) for manganese nodules in the Clarion-Clipperton Zone (ISA, 2011; Wedding et al., 2013, 2015; Lodge et al., 2014). For inactive sulfides, the precautionary approach discussed in the literature to date is a proposed framework for protection of at least $30 \%$ of the known inactive sulfide occurrences (as reported in the InterRidge Vents Database) within a network of APEIs distributed down the axis of the Mid-Atlantic Ridge (Dunn et al., 2018). The proposed framework is based on physico-chemical proxies (e.g., particulate organic carbon flux, depth, slope) that indicate a continuum of representative habitats along a latitudinal gradient and across the ridge axis. Rules for determining representativity itself need definition in the context of inactive sulfides. For example, will differences in the relative abundance of taxa be sufficient to define different faunas (Boschen et al., 2016) or will differences in taxonomic composition also be necessary? Will differences in isotopic niches across sites be critical to assessing heterogeneity and representativity?

More detailed baseline knowledge of inactive sulfide ecosystems is needed before an informed and plausibly effective network of representative protected inactive sulfide occurrences can be applied on a regional scale. A perennial issue for environmental management in a region is whether the local flora and fauna occur elsewhere, or if there is a high degree of geographic endemicity. Based on multiple lines of evidence, microbial communities of inactive sulfides may be connected globally and may be differentiated more by heterogeneity in the physical and chemical habitat than by geography (Toner et al., 2013; Christakis et al., 2018; Meier et al., 2018). For example, the character of the $\varepsilon$-Proteobacteria components of the community may be especially influenced by the time elapsed since cessation of hydrothermal activity and by water depth, rather than geographic separation (Kato et al., 2010). Empirical studies addressing questions of representativity-microbial or otherwise-seem still too few to reach definitive conclusions about endemicity.

\section{Environmental Impact Assessment}

Where there is threat of serious harm, mining contractors will be required to complete an environmental impact assessment (Durden et al., 2018; Clark et al., in press), including development of environmental baselines, monitoring, and mitigation programs for each mine site (Jones et al., 2019).
A number of features of inactive sulfides, including their small areal extent, patchy distribution, and environmental heterogeneity may dictate baseline requirements specific to these systems. To date, the only EIA that includes inactive sulfide ecosystems is for the Solwara 1 Prospect in Manus Basin (Gwyther, 2008). This EIA includes a list of environmental issues together with impact hypotheses, baseline measures, monitoring, and mitigation activities for each issue (Table 13.1, Gwyther, 2008). Specific reference is made to monitoring growth rates and colonization of fauna of inactive sulfides using permanent photo transects, time-lapse studies to assess succession, reproductive activity and behaviors, recolonization experiments, settlement collectors to monitor genetic diversity of recruits, transplants of corals and other organisms to facilitate recovery, and isotopic methods to assess the trophic status of the fauna of inactive sulfides. Best practices for elements of EIAs specific to inactive sulfides, including those developed by Nautilus Minerals, would benefit from review by scientific experts.

\section{Preservation Reference Zones (PRZ), Impact Reference Zones (IRZ)}

According to the draft exploitation regulations of the ISA, contractors will be obliged to provide coordinates of preservation reference zones (control areas with fauna representative of those that occur in impacted areas) and impact reference zones (areas subject to direct and indirect impacts of mining activities), together with monitoring and management plans for these areas as well as for the mine site(s) (ISA, 2018b). As emphasized above, the heterogeneity of inactive sulfide ecosystems in any given region is not well understood, and it remains an open question whether representative sulfide ecosystems exist in a given exploitation contract that can serve as the PRZ, and the IRZ for a mine site. A mine site itself may be comprised of multiple sulfide deposits (ISA, 2010; Section II/19.b.i.f), but details of requirements for PRZs, IRZs, and for that matter, Environmental Impact Assessment(s), for multiple sulfide deposits remain to resolved. Given that existing exploration contracts for sulfide resources extend for long distances (up to $1000 \mathrm{~km}$ ) along the Mid-Atlantic and SW Indian Ridges, it seems essential from an ecological perspective that mine sites (together with the PRZs and IRZs) be defined in a manner that takes into consideration the environmental settings of sulfide ecosystems in different regions of a contract area. If a single EIA extending the length (and breadth) of an exploitation contract is all that is required, will such an EIA be crafted with multiple 'sub-EIAs' to document that adequate measures are in place to protect inactive sulfide ecosystems from threat of serious harm?

\section{Avoiding Collateral Impacts on Vulnerable Marine Ecosystems}

At present, inactive sulfide systems are known primarily from explorations following discovery of active hydrothermal systems. As a consequence, they may be located proximal to (within hundreds of meters to kilometers) active vents, as well as other types of vulnerable ecosystems, such as sponge grounds and coral gardens. If such an inactive sulfide system is to be exploited, 
additional management measures will need to be in place to ensure there is no threat of serious harm to vulnerable marine ecosystems. Based on images of high densities and diversity of invertebrates on inactive sulfides (e.g., Figures 1D-H), evidence may emerge from baseline studies that inactive sulfide ecosystems in some regions may require protection.

\section{CONCLUSION}

Inactive sulfide ecosystems are poorly understood at present, and thus are an exciting frontier for ecology as well as economic geology, with many questions remaining about processes, distributions, and values. The scientific literature is often imprecise about what constitutes an inactive sulfide occurrence or potential deposit and will benefit from an understanding of the continuum from active to inactive status and use of a classification scheme.

While recent studies have focused on the composition of microorganisms associated with inactive sulfides, little is known about rates of microbial processes or the ability of microbial populations to sustain local metazoan communities. Anecdotal observations of invertebrate assemblages associated with inactive sulfides are common, but few quantitative studies using video and (or) sampling efforts have been undertaken, leaving us with little understanding of population and community processes, including growth, recruitment, competition, trophic interactions, connectivity, resilience, etc. Characteristic faunas of inactive sulfides vary from one ocean region to another and can even differ within a localized area, making it challenging to make generalizations about the ecology of these systems at this time. Invertebrate species associated with inactive sulfide occurrences likely colonize other hard substrata in a given region, but the extent to which densities, growth rates, and reproductive output are enhanced at inactive sulfides is uncertain. Nor is it certain

\section{REFERENCES}

Andersen, C., Theissen-Krah, S., Hannington, M., Rüpke, L., and Petersen, S. (2017). Faulting and off-axis submarine massive sulfide accumulation at slowspreading mid-ocean ridges: a numerical modeling perspective. Geochem. Geophys. Geosyst. 18, 2305-2320. doi: 10.1002/2017GC006880

Asakawa, E., Tara, K., Tsukahara, H., and Lee, S. (2018). "Multi-stage seismic survey for Seafloor Massive Sulphide (SMS) exploration," in Proceedings of the OCEANS-MTS/IEEE Kobe Techno-Oceans, Kobe.

Baker, E., and German, C. (2013). "On the global distribution of hydrothermal vent fields," in Mid-Ocean ridges: Hydrothermal interactions between the lithosphere and oceans. 148 Geophysical Monograph Series, eds C. R. German, J. Lin, and L. Parson (Washington, D.C: American Geophysical Union), 245-266. doi: 10.1029/148gm10

Baker, M. C., Ramirez-Llodra, E. Z., Tyler, P. A., German, C. R., Boetius, A., Cordes, E. E., et al. (2010). "Biogeography, ecology, and vulnerability of chemosynthetic ecosystems in the deep sea," in Life in the World's Oceans, ed. A. D. McIntyre (Hoboken, NJ: Wiley-Blackwell), 161-182. doi: 10.1002/9781444325508.ch9

Barco, R. A., Hoffman, C. L., Ramírez, G. A., Toner, B. M., Edwards, K. J., and Sylvan, J. B. (2017). In-situ incubation of iron-sulfur mineral reveals a diverse chemolithoautotrophic community and a new biogeochemical role for Thiomicrospira. Environ. Microbiol. 19, 1322-1337. doi: 10.1111/1462-2920. 13666 that there are any species endemic to the inactive sulfide habitat. If inactive sulfides beneath a sediment cover become mining prospects, then baseline information on the overlying sediment faunas will need to be collected and assessed in a regional context.

Investment in scientific study of inactive sulfide ecosystems is increasing as a consequence of interests in exploiting the minerals that form the substratum of these habitats. Acquisition and sharing of new knowledge will enable scientifically informed environmental management practices for these systems.

\section{AUTHOR CONTRIBUTIONS}

CVD conceived of and wrote the manuscript.

\section{FUNDING}

This project was supported by the Global Ocean Biodiversity Initiative through the International Climate Initiative (IKI; Grant No. 16_IV_049_Global_A_Global Ocean Biodiversity Initiative GOBI). The Federal Ministry for the Environment, Nature Conservation, and Nuclear Safety (BMU) supports IKI on the basis of a decision adopted by the German Bundestag.

\section{ACKNOWLEDGMENTS}

The author gratefully acknowledges T. Washburn for his assistance in searching for and reviewing literature on inactive sulfide ecosystems, A. Metaxas, R. Boschen-Rose, and D. Johnson for comments on the manuscript, colleagues who generously offered images of inactive sulfide ecosystems (R. Boschen-Rose, M. Cheadle, M. Clark, B. John, A. Rowden, A. Soule, and V. Tunnicliffe), and three peer reviewers for their valuable critiques and suggestions.

Beaulieu, S. E., and Szafranski, K. (2018). InterRidge Global Database of Active Submarine Hydrothermal Vent Fields, Version 3.4. World Wide Web Electronic Publication. Available at: http://vents-data.interridge.org/ (accessed July 15, 2019).

Bel'tenev, V. E., Lazareva, L. I., Cherkashev, G. A., Ivanov, V. I., Rozhdestvenskaya, I. I., Narkevskiy, E. V., et al. (2017). New hydrothermal sulfide fields of the MidAtlantic Ridge: yubileinoe (20(09' N) and Surprise (20(45.4' N). Dokl. Earth Sci. 476, 1010-1015. doi: 10.1134/s1028334x17090227

Bilenker, L. D., Romano, G. Y., and McKibben, M. A. (2016). Kinetics of sulfide mineral oxidation in seawater: implications for acid generation during in situ mining of seafloor hydrothermal vent deposits. Appl. Geochem. 75, 20-31. doi: 10.1016/j.apgeochem.2016.10.010

Bischoff, J., Rosenbauer, R., Aruscavage, P., Baedecker, P., and Crock, J. (1983). Seafloor massive sulfide deposits from 21 degrees $\mathrm{N}$, east pacific rise; juan de fuca ridge; and galapagos Rift: bulk chemical composition and economic implications. Econ. Geol. 78, 1711-1720. doi: 10.2113/gsecongeo.78.8.1711

Boschen, R., Rowden, A., Clark, M., Barton, S., Pallentin, A., and Gardner, J. (2015). Megabenthic assemblage structure on three New Zealand seamounts: implications for seafloor massive sulfide mining. Mar. Ecol. Prog. Ser. 523, 1-14. doi: 10.3354/meps11239

Boschen, R. E., Rowden, A. A., Clark, M. R., and Gardner, J. P. A. (2013). Mining of deep-sea seafloor massive sulfides: a review of the deposits, their benthic communities, impacts from mining, regulatory frameworks and management 
strategies. Ocean Coast. Manag. 84, 54-67. doi: 10.1016/j.ocecoaman.2013. 07.005

Boschen, R. E., Rowden, A. A., Clark, M. R., Pallentin, A., and Gardner, J. P. A. (2016). Seafloor massive sulfide deposits support unique megafaunal assemblages: implications for seabed mining and conservation. Mar. Environ. Res. 115, 78-88. doi: 10.1016/j.marenvres.2016.02.005

Carey, A. (1990). "Distributional ecology of selected megaepifauna on abyssal plains adjacent to gorda ridge, northeast pacific ocean," in Gorda Ridge: A Seafloor Spreading Center in the United States' Exclusive Economic Zone, ed. G. McMurray (New York, NY: Springer), 241-251. doi: 10.1007/978-1-4612-325 8-2_17

Cathles, L. M. (2011). What processes at mid-ocean ridges tell us about volcanogenic massive sulfide deposits. Mineralium Deposita 46, 659-663. doi: 10.1007/s00126-011-0329-8

Cherkashov, G. (2017). "Seafloor massive sulfide deposits: distribution and prospecting," in Deep-Sea Mining, ed. R. Sharma (Chem: Springer International Publishing).

Cherkashov, G., Poroshina, I., Stepanova, T., Ivanov, V., Bel'tenev, V., Lazareva, L., et al. (2010). Seafloor massive sulfides from the northern equatorial midatlantic ridge: new discoveries and perspectives. Mar. Georesources Geotechnol. 28, 222-239. doi: 10.1080/1064119X.2010.483308

Christakis, C. A., Polymenakou, P. N., Mandalakis, M., Nomikou, P., Kristoffersen, J. B., Lampridou, D., et al. (2018). Microbial community differentiation between active and inactive sulfide chimneys of the Kolumbo submarine volcano. Hell Volcanic. Arc. Extremophiles 22, 13-27. doi: 10.1007/s00792-0170971-x

Clark, M. R., Durden, J. M., and Christiansen, S. (in press). Environmental Impact Assessments for deep-sea mining: can we improve their future effectiveness? Mar. Policy 1-9. doi: 10.1016/j.marpol.2018.11.026

Collins, P. C., Kennedy, R., and Van Dover, C. L. (2012). A biological survey method applied to seafloor massive sulphides (SMS) with contagiously distributed hydrothermal-vent fauna. Mar. Ecol. Prog. Ser. 452, 89-107. doi: 10.3354/meps09646

Copley, J., Marsh, L., Glover, A., Hühnerbach, V., Nye, V., Reid, W., et al. (2016). Ecology and biogeography of megafauna and macrofauna at the first known deep-sea hydrothermal vents on the ultraslow-spreading Southwest Indian Ridge. Sci. Rep. 6, 39158. doi: 10.1038/srep39158

Corliss, J. B., Dymond, J., Gordon, L. I., Edmond, J. M., Von, R. P., Ballard, R. D., et al. (1979). Submarine thermal springs on the galapagos rift. Science 203, 1073-1083. doi: 10.1126/science.203.4385.1073

Cuvelier, D., Sarrazin, J., Colaço, A., Copley, J., Desbruyères, D., Glover, A. G., et al. (2009). Distribution and spatial variation of hydrothermal faunal assemblages at lucky strike (Mid-Atlantic Ridge) revealed by high-resolution video image analysis. Deep Sea Res. Part I Oceanogr. Res. Pap. 56, 2026-2040. doi: 10.1016/j. dsr.2009.06.006

Cuvelier, D., Sarrazin, J., Colaço, A., Copley, J. T., Glover, A. G., Tyler, P. A., et al. (2011). Community dynamics over 14 years at the eiffel tower hydrothermal edifice on the mid-atlantic ridge. Limnol. Oceanogr. 56, 1624-1640. doi: 10. 4319/lo.2011.56.5.1624

Desbruyères, D., Biscoito, M., Caprais, J. C., Colaço, A., Comtet, T., Crassous, P., et al. (2001). Variations in deep-sea hydrothermal vent communities on the Mid-atlantic ridge near the azores plateau. Deep. Res. 48, 1325-1346. doi: 10.1016/s0967-0637(00)00083-2

Dumke, I., Ludvigsen, M., Ellefmo, S. L., Søreide, F., Johnsen, G., and Murton, B. J. (2018). Underwater hyperspectral imaging using a stationary platform in the Trans-atlantic geotraverse hydrothermal field. IEEE Trans. Geosci. Remote Sens. 57, 2947-2962. doi: 10.1109/TGRS.2018.2878923

Dunn, D. C., Van Dover, C. L., Etter, R. J., Smith, C. R., Levin, L. A., Morato, T., et al. (2018). Astrategy for the conservation of biodiversity on mid-ocean ridges from deep-sea mining. Sci. Adv. 4:eaar4313. doi: 10.1126/sciadv.aar4313

Durden, J. M., Lallier, L. E., Murphy, K., Jaeckel, A., Gjerde, K., and Jones, D. O. B. (2018). Environmental Impact assessment process for deep-sea mining in 'the area.'. Mar. Policy 87, 194-202. doi: 10.1016/j.marpol.2017.10.013

Durden, J. M., Murphy, K., Jaeckel, A., Van Dover, C. L., Christiansen, S., Gjerde, K., et al. (2017a). A procedural framework for robust environmental management of deep-sea mining projects using a conceptual model. Mar. Policy 84, 193-201. doi: 10.1016/j.marpol.2017.07.002
Durden, J. M., Simon-Lledo, E., Gooday, A. J., and Jones, D. O. B. (2017b). Abundance and morphology of Paleodictyon nodosum, observed at the clarionclipperton zone. Mar. Biodivers. 47, 265-269. doi: 10.1007/s12526-0170636-0

Eberhard, C., Wirsen, C., and Janasch, H. (1995). Oxidation of polymetal sulfides by chemoautolithotrophic bacteria from dseep-sea hydrothermal vents. Geomicrobiol. J. 13, 145-164. doi: 10.1080/01490459509378014

Ecorys. (2014). https://webgate.ec.europa.eu/maritimeforum/sites/maritimeforum/ files/FGP96656_final_rep._formatted._november_2014.pdf (accessed September 10, 2017).

Edwards, K. (2004). "Formation and degradation of seafloor hydrothermal desposits," in Sulfur Biogeochemistry: Past and Present: Geological Society of America, Special Paper 379, eds J. Amend, K. Edwards, and T. Lyons (Boulder, CO: Geological Society of America), 83-96. doi: 10.1130/0-8137-2379-5.83

Edwards, K., McCollom, T., Konishi, H., and Buseck, P. (2003a). Seafloor bioalteration of sulfide minerals: results from in situ incubation studies. Geochim. Cosmochim. Acta. 67, 2843-2856. doi: 10.1016/s0016-7037(03) 00089-9

Edwards, K., Rogers, D., Wirsen, C., and Mccollom, T. (2003b). Isolation and characterization of novel psychrophilic, neutrophilic, alpha- and gammaProteobacteria from the deep dea. Environ. Microbiol. 69, 2906-2913. doi: 10. 1128/AEM.69.5.2906

Edwards, K. J., Bach, W., and McCollom, T. M. (2005). Geomicrobiology in oceanography: microbe-mineral interactions at and below the seafloor. Trends Microbiol. 13, 449-456. doi: 10.1016/j.tim.2005.07.005

Edwards, K. J., Bach, W., McCollom, T. M., and Rogers, D. R. (2004). Neutrophilic iron-oxidizing bacteria in the ocean: their habitats, diversity, and roles in mineral deposition, rock alteration, and biomass production in the deep-sea. Geomicrobiol. J. 21, 393-404. doi: 10.1080/01490450490485863

Embley, R. W., Jonasson, I. R., Perfit, M. R., Franklin, J. M., Tivey, M. A., Malahoff, A., et al. (1988). Submersible investigation of an extinct hydrothermal system on the galapagos ridge: sulfide mounds, stockwork zone, and differentiated lavas. Can. Mineral. 26, 517-539.

Erickson, K. L., Macko, S. A., and Van Dover, C. L. (2009). Evidence for a chemoautotrophically based food web at inactive hydrothermal vents (Manus Basin). Deep Sea Res. Part II Top. Stud. Oceanogr. 56, 1577-1585. doi: 10.1016/ j.dsr2.2009.05.002

Fahrig, L. (2017). Ecological responses to habitat fragmentation per se. Annu. Rev. Ecol. Evol. Syst. 48, 1-23. doi: 10.1146/annurev-ecolsys-110316-022612

Fallon, E., Frische, M., Petersen, S., Brooker, R., and Scott, T. (2019). Geological, mineralogical and textural impacts on the distribution of environmentally toxic trace elements in seafloor massive sulfide occurrences. Minerals 9:162. doi: $10.3390 / \min 9030162$

Fallon, E. K., Niehorster, E., Brooker, R. A., and Scott, T. B. (2018). Experimental leaching of massive sulphide from TAG active hydrothermal mound and implications for seafloor mining. Mar. Pollut. Bull. 126, 501-515. doi: 10.1016/ j.marpolbul.2017.10.079

Fallon, E. K., Petersen, S., Brooker, R. A., and Scott, T. B. (2017). Oxidative dissolution of hydrothermal mixed-sulphide ore: an assessment of current knowledge in relation to seafloor massive sulphide mining. Ore Geol. Rev. 86, 309-337. doi: 10.1016/j.oregeorev.2017.02.028

Flemming, C., and Trevors, J. (1989). Copper toxicity and chemistry in the environment: a review. Water Air. Soil Pollut. 44, 143-158. doi: 10.1007/ bf00228784

Fouquet, Y., Knott, R., Cambon, P., Fallick, A., Rickard, D., and Desbruyeres, D. (1996). Formation of large sulfide mineral deposits along fast spreading ridges. Example from off-axial deposits at $12\left(43^{\prime} \mathrm{N}\right.$ on the east pacific rise. Earth Planet. Sci. Lett. 144, 147-162. doi: 10.1016/0012-821x(96)00142-2

Francheteau, J., Needham, H., Choukroune, P., Juteau, T., Seguret, M., Ballard, R., et al. (1979). Massive deep-sea sulphide ore deposits discovered on the east pacific rise. Nature 277, 523-528. doi: 10.1038/277523a0

Franklin, J., Lydon, J., and Sangster, D. (1981). "Volcanic massive sulfide deposits," in Economic Geology, 75th Anniversary, ed. B. Skinner (New Haven CT: Econmic Geology Publishing Co), 627.

Fustec, A., Desbruyères, D., and Juniper, S. K. (1987). Deep-sea hydrothermal vent communities at $13(\mathrm{~N}$ on the east pacific rise: microdistribution and temporal variations. Biol. Ocean. 4, 121-164. doi: 10.1080/01965581.1987.10749487 
Gablina, I. F., Dobretsova, I. G., Beltenev, V. E., Lyutkevich, A. D., Narkevskii, E. V., and Gustaitis, A. N. (2012). Peculiarities of present-day sulfide mineralization at $19\left(15^{\prime}-20\left(08^{\prime}\right.\right.$ N. Mid Atlantic Ridge. Dokl. Earth Sci. 442, 163-167. doi: $10.1134 / \mathrm{s} 1028334 \times 1202002 \mathrm{x}$

Galkin, S. V. (1997). Megafauna associated with hydrothermal vents in the manus back-arc basin (Bismarck Sea). Mar. Geol. 142, 197-206. doi: 10.1016/S00253227(97)00051-50

Genin, A., Dayton, P., Lonsdale, P., and Spiess, F. (1986). Corals on seamount peaks provide evidence of current accelleration over deep-sea topography. Nature 324, 698-699. doi: 10.1038/320129a0

German, C. R., Petersen, S., and Hannington, M. D. (2016). Hydrothermal exploration of mid-ocean ridges: where might the largest sulfide deposits be forming? Chem. Geol. 420, 114-126. doi: 10.1016/j.chemgeo.2015.11.006

Godet, L., Zelnio, K. A., and Van Dover, C. L. (2011). Scientists as stakeholders in conservation of hydrothermal vents. Conserv. Biol. 25, 214-222. doi: 10.1111/j. 1523-1739.2010.01642.x

Goodfellow, W. D. C., and Franklin, M. (1993). Geology, mineralogy, and chemistry of sediment-hosted clastic massive sulfides in shallow cores, Middle Valley, Northern Juan de Fuca Ridge. Econ. Geol. 88, 2037-2068. doi: 10.2113/ gsecongeo.88.8.2037

Gwyther, D. (2008). Environmental Impact Statement, Nautilus Minerals Niugini Limited, Solwara 1 Project, Executive Summary. Vancouver, CA: Nautilus Minerals.

Haldar, S. (2013). Introduction to Mineralogy and Petrology. Amsterdam, NE: Elsevier.

Han, Y., Gonnella, G., Adam, N., Schippers, A., Burkhardt, L., Kurtz, S., et al. (2018). Hydrothermal chimneys host habitat-specific microbial communities: analogues for studying the possible impact of mining seafloor massive sulfide deposits. Sci. Rep. 8, 1-12. doi: 10.1038/s41598-018-28613-5

Hannington, M., Jamieson, J., Monecke, T., Petersen, S., and Beaulieu, S. (2011). The abundance of seafloor massive sulfide deposits. Geology 39, 1155-1158. doi: $10.1130 / \mathrm{G} 32468.1$

Hannington, M., and Monecke, T. (2009). Global exploration models for polymetallic sulphides in the area: an assessment of lease block selection under the draft regulations on prospecting and exploration for polymetallic sulphides. Mar. Georesources Geotechnol. 27, 132-159. doi: 10.1080/10641190802680614

Hannington, M. D. (1993). The formation of atacamite during weathering of sulfides on the modern seafloor. Can. Mineral. 31, 945-956.

Hauton, C., Brown, A., Thatje, S., Mestre, N. C., Bebianno, M. J., Martins, I., et al. (2017). Identifying toxic impacts of metals potentially released during deep-sea mining-a synthesis of the challenges to quantifying risk. Front. Mar. Sci. 4:368. doi: $10.3389 /$ fmars. 2017.00368

Hekinian, R., Renard, V., and Cheminee, J. (1983). "Hydrothermal deposits on the east pacific rise near 13 degrees $\mathrm{N}$ : geological setting and distribution of active sulfide chimneys," in Hydrothermal Processes at Seafloor Spreading Centers, eds P. Rona, K. Bostrom, L. Laubier, and K. Smith (New York, NY: Plenum Press), 571-592.

Herzig, P., and Hannington, M. (1995). Polymetallic massive sulfides at the modem seafloor a review. Ore Geol. Rev. 10, 95-115. doi: 10.1016/0169-1368(95)00 009-7

Herzig, P. M., Becker, K. P., Stoffers, P., Bäcker, H., and Blum, N. (1988). Hydrothermal silica chimney fields in the galapagos spreading center at $86(\mathrm{~W}$. Earth Planet. Sci. Lett. 89, 261-272. doi: 10.1016/0012-821X(88)90115-X

Hoshino, T., Kuratomi, T., Morono, Y., Hori, T., Oiwane, H., Kiyokawa, S., et al. (2016). Ecophysiology of Zetaproteobacteria associated with shallow hydrothermal iron-oxyhydroxide deposits in nagahama bay of satsuma iwo-jima. Japan. Front. Microbiol. 6, 1-11. doi: 10.3389/fmicb.2015. 01554

Humphris, S. E., and Kleinrock, M. C. (1996). Detailed morphology of the TAG active hydrothermal mound: insights into its formation and growth. Geophys. Res. Lett. 23, 3443-3446. doi: 10.1029/96gl03079

ISA (2010). ISBA/16a/12/rev1 Decision of the Assembly of the International Seabed Authority relating to the regulations on prospecting and exploration for polymetallic sulphides in the Area. Available at: https://www.isa.org.jm/ documents/isba16a12-rev-1 (accessed July 15, 2019).

ISA (2011). ISBA/17/LTC/7 Environmental Management Plan for the ClarionClipperton Zone. 1-18. Available at: https://www.isa.org.jm/documents/ isba17ltc7 (accessed July 15, 2019).
ISA (2018a). Design of IRZs and PRZs in deep-sea mining contract areas. Available at: https://www.isa.org.jm/workshop/workshop-design-impact-referencezones-and-preservation-reference-zones-area (accessed July 15 2019).

ISA (2018b). Draft Regulations on Exploitation of Mineral Resources in the Area. Int. Seabed Auth. Available at: https://www.isa.org.jm/document/isba24ltcwp1rev1 (accessed July 15, 2019).

Jamieson, J. W., Clague, D. A., and Hannington, M. D. (2014). Hydrothermal sulfide accumulation along the endeavour segment, juan de fuca ridge. Earth Planet. Sci. Lett. 395, 136-148. doi: 10.1016/j.epsl.2014.03.035

Jones, D. O. B., Amon, D. J., and Chapman, A. S. A. (2018). Mining deep-ocean mineral deposits: what are the ecological risks? Elements 14, 325-330. doi: 10.2138/gselements.14.5.325

Jones, D. O. B., Durden, J. M., Murphy, K., Gjerde, K. M., Gebicka, A., Colaço, A., et al. (2019). Existing environmental management approaches relevant to deep-sea mining. Mar. Policy. 103, 172-181. doi: 10.1016/j.marpol.2019.01.006

Juliani, C., and Ellefmo, S. L. (2018). Probabilistic estimates of permissive areas for undiscovered seafloor massive sulfide deposits on an arctic mid-ocean ridge. Ore Geol. Rev. 95, 917-930. doi: 10.1016/j.oregeorev.2018.04.003

Karl, D. M., Wirsen, C. O., and Jannasch, H. W. (1980). Deep-sea primary production at the galápagos hydrothermal vents. Science 207, 1345-1347. doi: 10.1126/science.207.4437.1345

Kato, S., Ikehata, K., Shibuya, T., Urabe, T., Ohkuma, M., and Yamagishi, A. (2015). Potential for biogeochemical cycling of sulfur, iron and carbon within massive sulfide deposits below the seafloor. Environ. Microbiol. 17, 1817-1835. doi: 10.1111/1462-2920.12648

Kato, S., Shibuya, T., Takaki, Y., Hirai, M., Nunoura, T., and Suzuki, K. (2018). Genome-enabled metabolic reconstruction of dominant chemosynthetic colonizers in deep-sea massive sulfide deposits. Environ. Microbiol. 20, 862-877. doi: 10.1111/1462-2920.14032

Kato, S., Takano, Y., Kakegawa, T., Oba, H., Inoue, K., Kobayashi, C., et al. (2010). Biogeography and biodiversity in sulfide structures of active and inactive vents at deep-sea hydrothermal fields of the Southern Mariana Trough. Appl. Environ. Microbiol. 76, 2968-2979. doi: 10.1128/AEM.00478-10

Kato, S., and Yamagishi, A. (2015). "Prokaryotes in metal deposits on the deep seafloor," in Deep Sea: Biodiversity, Human Dimension and Ecological Significance, Chap. Hauppauge, NY, ed. N. Wilson (Nova Science Publishers), $103-134$.

Kato, S., and Yamagishi, A. (2016). A novel large filamentous deltaproteobacterium on hydrothermally inactive sulfide chimneys of the Southern mariana trough. Deep Sea Res. Part Oceanogr. Res. Pap. 110, 99-105. doi: 10.1016/j.dsr.2015. 12.015

Kelley, D. S., Karson, J. A., Fru, G. L., Yoerger, D. R., Shank, T. M., Butterfield, D. A., et al. (2005). A serpentinite-hosted ecosystem: the lost city hydrothermal field. Science 307, 1428-1434. doi: 10.1126/science.1102556

Knight, R. D., Roberts, S., and Cooper, M. J. (2018). Investigating monomineralic and polymineralic reactions during the oxidation of sulphide minerals in seawater: implications for mining seafloor massive sulphide deposits. Appl. Geochem. 90, 63-74. doi: 10.1016/j.apgeochem.2017.12.027

Kouris, A., Kim Juniper, S., Frébourg, G., and Gaill, F. (2007). Protozoan-bacterial symbiosis in a deep-sea hydrothermal vent folliculinid ciliate (Folliculinopsis sp.) from the Juan de Fuca Ridge. Mar. Ecol. 28, 63-71. doi: 10.1111/j.14390485.2006.00118.x

Kouris, A., Limén, H., Stevens, C. J., and Juniper, S. K. (2010). Blue mats: faunal composition and food web structure in colonial ciliate (Folliculinopsis sp.) mats at northeast Pacific hydrothermal vents. Mar. Ecol. Prog. Ser. 412, 93-101. doi: 10.3354/meps08675

Krasnov, S. G., Cherkashev, G. A., Stepanova, T. V., Batuyev, B. N., Krotov, A. G., Malin, B. V., et al. (1995). Detailed geological studies of hydrothermal fields in the North Atlantic. Geol. Soc. 87, 43-64. doi: 10.1144/gsl.sp.1995.087. 01.05

LaBella, A. (2017). Gene Flow and Population Structure in Two Species of Deepsea Mollusks Assessed Using Multilocus Amplicon Datasets. Ph.D. Dissertation, Duke University, Durham, NC (accessed July 15, 2019).

Lalou, C., Reyss, J. L., and Brichet, E. (1998). Age of sub-bottom sulfide samples at the TAG active mound. Proc. Ocean Drill. Progr. 158, 111-117. doi: 10.2973/ odp.proc.sr.158.214.1998

Lalou, C., Reyss, J.-L., Brichet, E., Rona, P. A., and Thompson, G. (1995). Hydrothermal activity on a $10^{\wedge} 5$-year scale at a slow-spreading ridge, TAG 
hydrothermal field, mid-atlantic ridge 26oN. J. Geophys. Res. 100, 17855-17862. doi: $10.1029 / 95 j \mathrm{~b} 01858$

Le Bris, N., Yücel, M., Das, A., Sievert, S. M., LokaBharathi, P., and Girguis, P. R. (2019). Hydrothermal energy transfer and organic carbon production at the deep seafloor. Front. Mar. Sci. 5:1-24. doi: 10.3389/fmars.2018.00531

Lehrmann, B., Stobbs, I., Lusty, P., and Murton, B. (2018). Insights into extinct seafloor massive sulfide mounds at the TAG. Mid Atlantic Ridge. Minerals 8, 302. doi: $10.3390 / \mathrm{min} 8070302$

Levin, L. A., Mendoza, G. F., Konotchick, T., and Lee, R. (2009). Macrobenthos community structure and trophic relationships within active and inactive Pacific hydrothermal sediments. Deep. Res. Part II Top. Stud. Oceanogr. 56, 1632-1648. doi: 10.1016/j.dsr2.2009.05.010

Levin, L. A., Mengerink, K., Gjerde, K. M., Rowden, A. A., Van Dover, C. L., Clark, M. R., et al. (2016). Defining "serious harm" to the marine environment in the context of deep-seabed mining. Mar. Policy 74, 245-259. doi: 10.1016/j.marpol. 2016.09 .032

Li, J., Cui, J., Yang, Q., Cui, G., Wei, B., Wu, Z., et al. (2017). Oxidative weathering and microbial diversity of an inactive seafloor hydrothermal sulfide chimney. Front. Microbiol. 8:1-21. doi: 10.3389/fmicb.2017.01378

Liang, J., Tao, C., Yang, W., Liao, S., and Huang, W. (2018). 230Th/238U dating of sulfide chimneys in the Longqi-1 hydrothermal Field, Southwest Indian Ridge. Acta. Geol. Sin. 92 Supp. 2, 77-78. doi: 10.1111/1755-6724.14202

Limén, H., Juniper, S. K., Tunnicliffe, V., and Clément, M. (2006). Benthic community structure on two peaks of an erupting seamount: northwest Rota-1 volcano, mariana arc, western Pacific. Cah. Biol. Mar. 47, 457-463.

Lin, W., Deng, A., Wang, Z., Li, Y., Wen, T., Wu, L. F., et al. (2014). Genomic insights into the uncultured genus "Candidatus magnetobacterium" in the phylum Nitrospirae. ISME J. 8, 2463-2477. doi: 10.1038/ismej.2014.94

Little, C. T. S., and Vrijenhoek, R. C. (2003). Are hydrothermal vent animals living fossils? Trends Ecol. Evol. 18, 582-588. doi: 10.1016/j.tree.2003.08.009

Liu, S., Hu, J., Zhang, R., Dai, Y., and Yang, H. (2016). Development of mining technology and equipment for seafloor massive sulfide deposits. Chin. J. Mech. Eng. 2, 863-870. doi: 10.3901/cjme.2016.0815.093

Lodge, M., Johnson, D., LeGurun, G., Wengler, M., Weaver, P., and Gunn, V. (2014). Seabed mining: international seabed authority environmental management plan for the clarion-clipperton zone. a partnership approach. Mar. Policy 49, 66-72. doi: 10.1016/j.marpol.2014. 04.006

Ludvigsen, M., Aasly, K., Ellefemo, S., Hilario, A., Ramirez-Llodra, E., Søreide, F., et al. (2016). NTNU Cruise Reports 2016 No 1. Available at: https://www. researchgate.net/publication/314177507_NTNU_Cruise_reports_2016_no_1_ -_MarMine_cruise_report_Arctic_Mid-Ocean_Ridge_15082016_-_05092016 (accessed July 15, 2019).

Macdonald, K. C., Becker, K., Spiess, F. N., and Ballard, R. D. (1980). Hydrothermal heat flux of the "black smoker" vents on the East Pacific Rise. Earth Planet. Sci. Lett. 48, 1-7. doi: 10.1126/science. 1201066

Marsh, L., Copley, J. T., Huvenne, V. A., Linse, K., Reid, W. D. K., Rogers, A. D., et al. (2012). Microdistribution of faunal assemblages at deep-sea hydrothermal vents in the Southern Ocean. PLoS One 7:e48348. doi: 10.1371/journal.pone. 0048348

McAllister, S., Moore, R., Gartman, A., Luther, G. I., Emerson, D., and Chan, C. (2018). Marine Fe-oxidizing Zetaproteobacteria: historical, ecological, and genomic perspectives. bioRxiv

McCaig, A. M., Cliff, R. A., Escartin, J., Fallick, A. E., and MacLeod, C. J. (2007). Oceanic detachment faults focus very large volumes of black smoker fluids. Geology 35, 935-938. doi: 10.1130/G23657A.1

McCollom, T. M. (2000). Geochemical constraints on primary productivity in submarine hydrothermal vent plumes. Deep. Res. Part I Oceanogr. Res. Pap. 47, 85-101. doi: 10.1016/s0967-0637(99)00048-5

McLean, J. H. (1990). Neolepetopsidae, a new docoglossate limpet family from hydrothermal vents and its relevance to patellogastropod evolution. J. Zool. 222, 485-528. doi: 10.1111/j.1469-7998.1990.tb04047.x

Meier, D. V., Pjevac, P., Bach, W., Markert, S., Schweder, T., Jamieson, J., et al. (2018). Microbial metal-sulfide oxidation in inactive hydrothermal vent chimneys suggested by metagenomic and metaproteomic analyses. Environ. Microbiol. 21, 682-701. doi: 10.1111/1462-2920. 14514
Melekestseva, I., Maslennikov, V., Safina, N., Nimis, P., Maslennikova, S., Beltenev, V., et al. (2018). Sulfide breccias from the semenov-3 hydrothermal field, midatlantic ridge: authigenic mineral formation and trace element pattern. Minerals 8, 321. doi: $10.3390 / \mathrm{min} 8080321$

Meysman, F. J. R. (2018). Cable Bacteria take a new breath using long-distance electricity. Trends Microbiol. 26, 411-422. doi: 10.1016/j.tim.2017.10.011

Miller, K. A., Thompson, K. F., Johnston, P., and Santillo, D. (2018). An overview of seabed mining including the current state of development, environmental impacts, and knowledge gaps. Front. Mar. Sci. 4:418. doi: 10.3389/fmars.2017. 00418

Ministry of Economy Trade and Industry (2017). World's first success in continuous ore lifting test for seafloor polymetallic sulphides. Available at: http://www.meti.go.jp/english/press/2017/0926_004.html (accessed February $18,2019)$

Monecke, T., Petersen, S., Hannington, M. D., Grant, H., and Samson, I. (2016). The minor element endowment of modern sea-floor massive sulfide deposits and comparison with deposits hosted in ancient volcanic successions. Rev. Econ. Geol. 18, 245-306.

Müller, H., Schwalenberg, K., Reeck, K., Barckhausen, U., Schwarz-Schampera, U., Hilgenfeldt, C., et al. (2018). Mapping seafloor massive sulfides with the golden eye frequency-domain em profiler. First Break 36, 61-67.

Münch, U., Blum, N., and Halbach, P. (1999). Mineralogical and geochemical features of sulfide chimneys from the MESO zone, Central Indian Ridge. Chem. Geol. 155, 29-44. doi: 10.1016/S0009-2541(98)00139-139

Münch, U., Lalou, C., Halbach, P., and Fujimoto, H. (2001). Relict hydrothermal events along the super-slow Southwest Indian spreading ridge near $63\left(56^{\prime} \mathrm{E}-\right.$ Mineralogy, chemistry and chronology of sulfide samples. Chem. Geol. 177, 341-349. doi: 10.1016/s0009-2541(00)00418-6

Nakagawa, S., and Takai, K. (2008). Deep-sea vent chemoautotrophs: diversity, biochemistry and ecological significance. FEMS Microbiol. Ecol. 65, 1-14. doi: 10.1111/j.1574-6941.2008.00502.x

Nakamura, K., and Takai, K. (2015). "Geochemical constraints on potential biomass sustained by subseafloor water-rock interactions," in Subseafloor Biosphere Linked to Hydrothermal Systems: TAIGA Concept, eds J. I. Ishibashi, K. Okino, and M. Sunamura (Berlin: Springer), 11-30. doi: 10.1007/978-4-43154865-2_2

Narita, T., Oshika, J., Okamoto, N., Toyohara, T., and Miwa, T. (2015). Summary of environmental impact assessment for mining seafloor massive sulfides in Japan. J. Shipp. Ocean Eng. 5, 103-114. doi: 10.17265/2159-5879/2015.03.001

Niner, H. J., Ardron, J. A., Escobar, E. G., Gianni, M., Jaeckel, A., Jones, D. O. B., et al. (2018). Deep-sea mining with no net loss of biodiversity-an impossible aim. Front. Mar. Sci. 5:53. doi: 10.3389/fmars.2018.00053

Olins, H. C., Rogers, D. R., Frank, K. L., Vidoudez, C., and Girguis, P. R. (2013). Assessing the influence of physical, geochemical and biological factors on anaerobic microbial primary productivity within hydrothermal vent chimneys. Geobiology 11, 279-293. doi: 10.1111/gbi.12034

Olsen, B. R., Økland, I. E., Thorseth, I. H., Pedersen, R. B., and Rapp, H. T. (2016). Environmental Challenges Related to Offshore Mining and Gas Hydrate Extraction. 28. Available at: http://www.miljodirektoratet.no/no/Publikasjoner/ 2016/April-2016/Environmental-challenges-related-to-offshore-mining-andgas-hydrate-extraction/ (accessed July 15, 2019).

Orcutt, B., Bradley, J., Brazelton, W., Estes, E., Goordial, J., Huber, J., et al. (2018). Impacts of deep-sea mining on microbial ecosystem services. BioRxiv.

Page, H. M., Fisher, C. R., and Childress, J. J. (1990). Role of filter-feeding in the nutritional biology of a deep-sea mussel with methanotrophic symbionts. Mar. Biol. 104, 251-257. doi: 10.1007/BF01313266

Parmentier, E. M., and Spooner, E. T. C. (1978). A theoretical study of hydrothermal convection and the origin of the ophiolitic sulphide ore deposits of Cyprus. Earth Planet. Sci. Lett. 40, 33-44. doi: 10.1016/0012-821x(78) 90072-9

Paulsen, E. (2017). Community Structure and bioDiversity of the Benthic Megafauna at the Inactive Hydrothermal site Mohn's Treasure, on the Mohn's Ridge, Arctic Mid-Ocean Ridge (AMOR). MSc. Thesis, Norwegian University of Science and Technology, Trondheim

Pedersen, R., Thorseth, I., Nygard, T., Lilley, M., and Kelley, D. (2010). "Hydrothermal activity at the arctic mid-ocean ridges", in Diversity of Hydrothermal Systems on Slow Spreading Ridges. Geophysical Monograph Series 
188, eds P. Rona, C. Devey, J. Dyment, and B. Murton (Washington, D.C: American Geophysical Union), 67-89. doi: 10.1029/2008GM000783

Petersen, S., Hannington, M., and Krätschell, A. (2017). Technology developments in the exploration and evaluation of deep-sea mineral resources. Ann. Des Mines Responsab. Environ. 85, 14-18.

Petersen, S., Krätschell, A., Augustin, N., Jamieson, J., Hein, J. R., and Hannington, M. D. (2016a). News from the seabed - geological characteristics and resource potential of deep-sea mineral resources. Mar. Policy 70, 175-187. doi: 10.1016/ j.marpol.2016.03.012

Petersen, S., Krätschell, A., and Hannington, M. D. (2016b). The Current State of Global Activities Related to Deep-Sea Mineral Exploration and Mining. Available at: https://www.researchgate.net/publication/300328157_The_Current_State_ of_Global_Activities_Related_to_Deep-sea_Mineral_Exploration_and_Mining (accessed July 15, 2019).

Petersen, S., Lehrmann, B., and Murton, B. J. (2018). Modern seafloor hydrothermal systems: new perspectives on ancient ore-forming processes. Elements 14, 307-312. doi: 10.2138/gselements.14.5.307

Pettibone, M. (1989). Two new species of harmothoeinae (Polychaeta: Polynoidae) from the east pacific rise, collected by alvin dives 2000 and 2003. Proc. Biol. Soc. Washingt. 102, 305-310.

Peukert, A., Petersen, S., Greinert, J., and Charlot, F. (2018). Seabed Mining," in Submarine Geomorphology. Berlin: Springer.

Plouviez, S., Schultz, T. F., McGinnis, G., Minshall, H., Rudder, M., and Van Dover, C. L. (2013). Genetic diversity of hydrothermal-vent barnacles in Manus Basin. Deep. Res. Part I Oceanogr. Res. Pap. 82, 73-79. doi: 10.1016/j.dsr.2013.08.004

Popoola, S., Han, X., Wang, Y., Qiu, Z., Ye, Y., and Cai, Y. (2019). Mineralogical and geochemical signatures of metalliferous sediments in Wocan-1 and Wocan2 hydrothermal sites on the Carlsberg Ridge. Indian Ocean. Minerals 9:26. doi: $10.3390 / \min 9010026$

Reeves, E. P., Yoshinaga, M. Y., Pjevac, P., Goldenstein, N. I., Peplies, J., Meyerdierks, A., et al. (2014). Microbial lipids reveal carbon assimilation patterns on hydrothermal sulfide chimneys. Environ. Microbiol. 16, 3515-3532. doi: 10.1111/1462-2920.12525

Ren, M., Chen, J., Shao, K., Yu, M., and Fang, J. (2016). Quantitative prediction process and evaluation method for seafloor polymetallic sulfide resources. Geosci. Front. 7, 245-252. doi: 10.1016/j.gsf.2015.04.004

Rogers, D. R., Santelli, C. M., and Edwards, K. J. (2003). Geomicrobiology of deepsea deposits: estimating community diversity from low-temperature seafloor rocks and minerals. Geobiology 1, 109-117. doi: 10.1046/j.1472-4669.2003. 00009.x

Rona, P., Hannington, M. D., Tivey, K., and Lalou, C. (1993). Active and relict seafloor hydrothermal mineralization at the TAG hydrothermal field. Mid Atlantic Ridge. Econ. Geol. 88, 1989-2017. doi: 10.2113/gsecongeo.88.8.1989

Rona, P. A. (2008). The changing vision of marine minerals. Ore Geol. Rev. 33, 618-666. doi: 10.1016/j.oregeorev.2007.03.006

Rona, P. A., Klinkhammer, G., Nelsen, T. A., Trefry, J. H., and Elderfield, H. (1986). Black smokers, massive sulphides and vent biota at the Mid-Atlantic Ridge. Nature 321, 33-37. doi: 10.1038/321033a0

Rona, P. A., Seilacher, A., de Vargas, C., Gooday, A. J., Bernhard, J. M., Bowser, S., et al. (2009). Paleodictyon nodosum: a living fossil on the deep-sea floor. Deep. Res. Part II Top. Stud. Oceanogr. 56, 1700-1712. doi: 10.1016/j.dsr2.2009. 05.015

Safipour, R., Hölz, S., Jegen, M., and Swidinsky, A. (2018). A first application of a marine inductive source electromagnetic configuration with remote electric dipole receivers: palinuro seamount, tyrrhenian sea. Geophys. Prospect. 66, 1415-1432. doi: 10.1111/1365-2478.12646

Schrenk, M., Kelley, D., Delaney, J., and Baross, J. (2003). Incidence and diversity of microorganisms within the walls of an active deep-sea sulfide chimney. Appl. Environ. Microbiol. 69, 3580-3592. doi: 10.1128/AEM.69.6.3580-3592.2003

Schwalenberg, K., Müller, H., and Engels, M. (2016). "Seafloor massive sulfide eploration - a new field of activity for marine electromagnetics," in Proceedings of the EAGE/DGG Workshop on Deep Mineral Exploration, Münster.

Sen, A., Podowski, E. L., Becker, E. L., Shearer, E. A., Gartman, A., Luther, G. W., et al. (2014). Community succession in hydrothermal vent habitats of the eastern lau spreading center and valu fa ridge. Tonga. Limnol. Oceanogr. 59, 1510-1528. doi: 10.4319/lo.2014.59.5.1510

Simpson, S. L., and Spadaro, D. A. (2016). Bioavailability and chronic toxicity of metal sulfide minerals to benthic marine invertebrates: implications for deep sea exploration, mining and tailings disposal. Environ. Sci. Technol. 50, 4061-4070. doi: $10.1021 /$ acs.est.6b00203

Smith, K. (1985). Deep-sea hydrothermal vent mussels: nutritional state and distribution at the galapagos rift. Ecology 66, 1067-1080. doi: 10.2307/1940566

Soule, A., Seewald, J., Wankel, S., Michel, A., Beinart, R., Escobar Briones, E., et al. (2018). Exploration of the northern guaymas basin. Oceanogr. Suppl. 31, 39-41.

Spiess, F., Macdonald, K., Atwater, T., Ballard, B., Carranza, A., Cordoba, D., et al. (1980). East pacific rise: hot spring and geophysical experiments. Science 207, 1421-1433.

Steen, I. H., Dahle, H., Stokke, R., Roalkvam, I., Daae, F. L., Rapp, H. T., et al. (2016). Novel barite chimneys at the loki's castle vent field shed light on key factors shaping microbial communities and functions in hydrothermal systems. Front. Microbiol. 6:1-13. doi: 10.3389/fmicb.2015.01510

Stohs, S. J., and Bagchi, D. (1995). Oxidative mechanisms in the toxicity of metal ions. Free Radic. Biol. Med. 18, 321-336. doi: 10.1016/0891-5849(94)00159-H

Strens, M. R., and Cann, J. R. (1986). A fracture-loop thermal balance model of black smoker circulation. Tectonophysics 122, 307-324. doi: 10.1016/00401951(86)90149-6

Suzuki, Y., Inagaki, F., Takai, K., Nealson, K. H., and Horikoshi, K. (2004). Microbial diversity in inactive chimney structures from deep-sea hydrothermal systems. Microb. Ecol. 47, 186-196. doi: 10.1007/s00248-003-1014-y

Suzuki, Y., Kojima, S., Sasaki, T., Suzuki, M., Utsumi, T., Watanabe, H., et al. (2006). Host-symbiont relationships in hydrothermal vent gastropods of the genus Alviniconcha from the Southwest Pacific. Appl. Environ. Microbiol. 72, 1388-1393. doi: 10.1128/AEM.72.2.1388

Sylvan, J. B., Toner, B. M., and Edwards, K. J. (2012). Life and death of deep-sea vents: bacterial diversity and ecosystem succession on inactive hydrothermal sulfides. mBio 3, e279-e211. doi: 10.1128/mBio.00279-211

Tao, C., Li, H., Jin, X., Zhou, J., Wu, T., He, Y., et al. (2014). Seafloor hydrothermal activity and polymetallic sulfide exploration on the southwest Indian ridge. Chin. Sci. Bull. 59, 2266-2276. doi: 10.1007/s11434-014-0182-0

Tao, C., Lin, J., Guo, S., Chen, Y. J., Wu, G., Han, X., et al. (2012). First active hydrothermal vents on an ultraslow-spreading center: southwest Indian Ridge. Geology 40, 47-50. doi: 10.1130/G32389.1

Thaler, A. (2012). Population genetics of species associated with deep-sea hydrothermal vents in the Western Pacific. Dissertation, Ph.D. Duke University, Durham, NC.

Thaler, A., Plouviez, S., Saleu, W., Alei, F., Jacobson, A., Boyle, E., et al. (2014). Comparative population structure of two deep-sea hydrothermalvent-associated decapods (Chorocaris sp. 2 and Munidopsis lauensis) from southwestern Pacific back-arc basins. PLoS One 9:1-13. doi: 10.1371/journal. pone. 0101345

Toner, B. M., Lesniewski, R. A., Marlow, J. J., Briscoe, L. J., Santelli, C. M., Bach, W., et al. (2013). Mineralogy drives bacterial biogeography of hydrothermally inactive seafloor sulfide deposits. Geomicrobiol. J. 30, 313-326. doi: 10.1080/ 01490451.2012 .688925

Toner, B. M., Rouxel, O. J., Santelli, C. M., Bach, W., and Edwards, K. J. (2016). Iron transformation pathways and redox micro-environments in seafloor sulfidemineral deposits: spatially resolved Fe XAS and (57/54Fe observations. Front. Microbiol. 7:1-17. doi: 10.3389/fmicb.2016.00648

Tornos, F., Peter, J. M., Allen, R., and Conde, C. (2015). Controls on the siting and style of volcanogenic massive sulphide deposits. Ore Geol. Rev. 68, 142-163. doi: 10.1016/j.oregeorev.2015.01.003

Tunnicliffe, V., Botros, M., De Burgh, M. E., Dinet, A., Johnson, H. P., Juniper, S. K., et al. (1986). Hydrothermal vents of explorer ridge, northeast pacific. Deep Sea Res. Part A, Oceanogr. Res. Pap. 33, 401-412. doi: 10.1016/0198-0149(86) 90100-7

UN News Centre (2015). UN adopts new global goals, charting sustainable development for people and planet by 2030. Available at: https:// news.un.org/en/story/2015/09/509732-un-adopts-new-global-goals-chartingsustainable-development-people-and-planet (accessed July 15, 2019).

Van Dover, C. (2007). “The biological environment of polymetallic sulphides deposits, the potential impact of exploration and mining on this environment, and data required to establish environmental baselines in exploration areas," in proceedings of the Polymetallic Sulphides and Cobalt-rich Ferromanganese crust Deposits: Establishment of Environmental Baselines and an Associated Monitoring Programme during, Kingston. 
Van Dover, C., Arnaud-Haond, S., Gianni, M., Helmreich, S., Huber, J., Jaeckel, A., et al. (2018). Scientific rationale and international obligations for protection of active hydrothermal vent ecosystems from deep-sea mining. Mar. Policy 90, 20-28. doi: 10.1016/j.marpol.2018.01.020

Van Dover, C., Grassle, F., and Boudiras, M. (1990). "Hydrothermal vent fauna of escanaba trough (gorda ridge)," in Gorda Ridge: A Seafloor Spreading Center in the United States' Exclusive Economic Zone, ed. G. McMurray (New York, NY: Springer), 285-287. doi: 10.1007/978-1-4612-3258-2_21

Van Dover, C. L. (2000). The Ecology of Deep-Sea Hydrothermal Vents. Princeton, NJ: Princeton University Press.

Van Dover, C. L. (2011). Mining seafloor massive sulphides and biodiversity: what is at risk? ICES J. Mar. Sci. 68, 341-348. doi: 10.1093/icesjms/fsq086

Van Dover, C. L. (2014). Impacts of anthropogenic disturbances at deep-sea hydrothermal vent ecosystems: a review. Mar. Environ. Res. 102, 59-72. doi: 10.1016/j.marenvres.2014.03.008

Van Dover, C. L., Ardron, J., Escobar, E., Gianni, M., Gjerde, K., Jaeckel, A., et al. (2017). Biodiversity loss from deep-sea mining. Nat. Geosci. 10, 464-465.

Van Dover, C. L., Fry, B., Grassle, J. F., Humphris, S., and Rona, P. A. (1988). Feeding biology of the shrimp Rimicaris exoculata at hydrothermal vents on the mid-atlantic ridge. Mar. Biol. 98, 209-216. doi: 10.1007/BF003 91196

Van Dover, C. L., Humphris, S. E., Fornari, D., Cavanaugh, C. M., Collier, R., Goffredi, S. K., et al. (2001). Biogeography and ecological setting of Indian Ocean hydrothermal vents. Science 294, 818-823. doi: 10.1126/science. 1064574

Vanderzwaag, D. (2002). The Precautionary Principle and marine environmental protection: slippery shores, rough seas, and rising normative tides. Ocean Dev. Int. Law 33, 165-188. doi: 10.1080/0090832029005475

Weaver, P. P. E., Billett, D. S. M., and Van Dover, C. L. (2018). "Environmental risks of deep-sea mining," in Handbook on Marine Environment Protection, eds M. Salomon and T. Markus (Berlin: Springer International Publishing AG), 215-245.

Wedding, L. M., Friedlander, A. M., Kittinger, J. N., Watling, L., Gaines, S. D., Bennett, M., et al. (2013). From principles to practice: a spatial approach to systematic conservation planning in the deep sea. Proc. R. Soc. B Biol. Sci. 280, 20131684. doi: 10.1098/rspb.2013.1684
Wedding, L. M., Reiter, S. M., Smith, C. R., Gjerde, K. M., Kittinger, J. N., Friedlander, A. M., et al. (2015). Managing mining of the deep seabed. Science 349, 144-145. doi: 10.1126/science.aac6647

Wheeler, A. J., Murton, B., Copley, J., Lim, A., Carlsson, J., Collins, P., et al. (2013). Moytirra: discovery of the first known deep-sea hydrothermal vent field on the slow-spreading mid-atlantic ridge north of the azores. Geochem., Geophys. Geosyst. 14, 4170-4184. doi: 10.1002/ggge.20243

Wirsen, C. O., Jannasch, H. W., and Molyneaux, S. J. (1993). Chemosynthetic microbial activity at mid-atlantic ridge hydrothermal vent sites. J. Geophys. Res. 98, 9693-9703. doi: 10.1029/92JB01556

Zhang, L., Kang, M., Xu, J., Xu, J., Shuai, Y., Zhou, X., et al. (2016). Bacterial and archaeal communities in the deep-sea sediments of inactive hydrothermal vents in the southwest india ridge. Sci. Rep. 6, 1-11. doi: 10.1038/srep25982

Zhou, Y., Zhang, D., Zhang, R., Liu, Z., Tao, C., Lu, B., et al. (2018). Characterization of vent fauna at three hydrothermal vent fields on the Southwest Indian Ridge: implications for biogeography and interannual dynamics on ultraslow-spreading ridges. Deep. Res. Part 1 Oceanogr. Res. Pap. 137, 1-12. doi: 10.1016/j.dsr.2018.05.001

Zierenberg, R., Koski, R., Morton, J., Bouse, R., and Shanks, W. I. (1993). Genesis of massive sulfide deposits on a sediment-covered spreading, escanaba trough, southern gorda ridge. Econ. Geol. 88, 2069-2098. doi: 10.2113/gsecongeo.88.8. 2069

Conflict of Interest Statement: The author declares that the research was conducted in the absence of any commercial or financial relationships that could be construed as a potential conflict of interest.

The reviewer ER-L declared a past co-authorship with the author CVD, to the handling Editor.

Copyright (C) 2019 Van Dover. This is an open-access article distributed under the terms of the Creative Commons Attribution License (CC BY). The use, distribution or reproduction in other forums is permitted, provided the original author(s) and the copyright owner(s) are credited and that the original publication in this journal is cited, in accordance with accepted academic practice. No use, distribution or reproduction is permitted which does not comply with these terms. 